Florida International University FIU Digital Commons

FIU Electronic Theses and Dissertations

University Graduate School

$11-25-2002$

\title{
Chicle commercialization: institutions, sustainability and green markets
}

Tineke A. De Vries

Florida International University

DOI: $10.25148 /$ etd.FI14062226

Follow this and additional works at: https://digitalcommons.fiu.edu/etd

Part of the Latin American Languages and Societies Commons

\section{Recommended Citation}

De Vries, Tineke A., "Chicle commercialization: institutions, sustainability and green markets" (2002). FIU Electronic Theses and Dissertations. 2756.

https://digitalcommons.fiu.edu/etd/2756

This work is brought to you for free and open access by the University Graduate School at FIU Digital Commons. It has been accepted for inclusion in FIU Electronic Theses and Dissertations by an authorized administrator of FIU Digital Commons. For more information, please contact dcc@fiu.edu. 
Miami, Florida

\section{CHICLE COMMERCIALIZATION: INSTITUTIONS, SUSTAINABILITY AND GREEN MARKETS}

A thesis submitted in partial fulfillment of the

requirements for the degree of

MASTER OF ARTS

in

LATIN AMERICAN AND CARIBBEAN STUDIES

by

Tineke A. de Vries

2002 
To: Dean Arthur W. Herriott

College of Arts and Sciences.

This thesis, written by Tineke A. de Vries, and entitled Chicle commercialization: Institutions, Sustainability, and Green Markets, having been approved in respect to style and intellectual content, is referred to you for judgment.

We have read this thesis and recommend it to be approved

Karen Paul

Astrid Arraras

David Bray, Major Professor

Date of defense: November 25, 2002

The thesis of Tineke A. de Vries is approved.

Dean Arthur W. Herriott College of Arts and Sciences

Dean Douglas Wartzok University Graduate School

Florida International University, 2002 


\section{ABSTRACT OF THE THESIS}

\section{CHICLE COMMERCIALIZATION: INSTITUTIONS, SUSTAINABILITY AND}

\section{GREEN MARKETS}

by

Tineke A. de Vries

Florida International University, 2002

Miami, Florida

Professor David Bray, Major Professor

The purpose of this thesis was to investigate the central question: "How the institutional factors, sustainability aspects, marketing and green markets condition the potential for chicle commercialization to increase incomes and to contribute to tropical forest preservation in Quintana Roo, Mexico?"

I reviewed general literature on chicle, Non Timber Forest Products, institutions, sustainability, marketing and green markets. During the summer of 2001 I held forty semi-structured interviews with relevant actors in Quintana Roo.

Main findings were that producers need to increase control over the production process. Under current extraction practices ecological sustainability is likely to be maintained, but underutilisation of the resource leads to an economic unstable situation. In marketing organic chewing gum health aspects need to be emphasized to improve the effectiveness of marketing.

It was concluded that green markets offer potential, institutional problems need to be addressed and emphasis on connecting to the emerging organic markets and marketing messages is necessary. 
I. LITERATURE REVIEW

II. CHICLE; ECOLOGICAL, TECHNICAL AND HISTORICAL FACTS. .............. 12

Technical facts of chicle ........................................................................................ 14

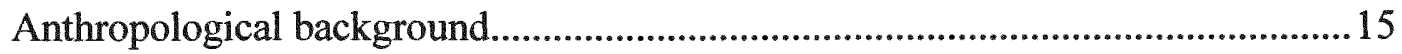

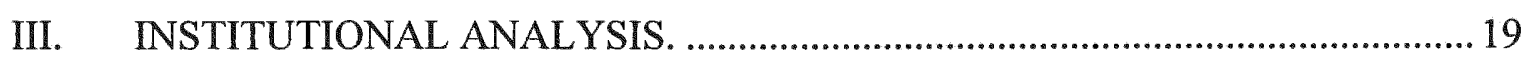

The institutional history and current situation. .....................................................19

Problems and Constraints for producers ...............................................................26

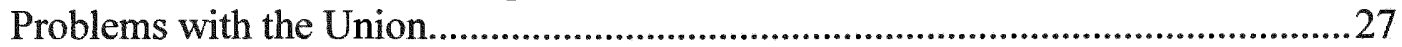

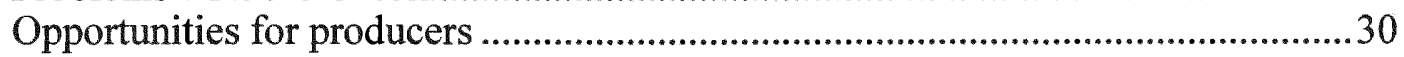

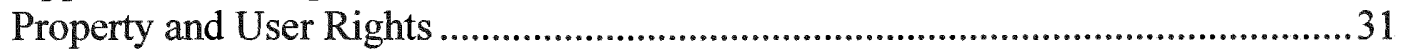

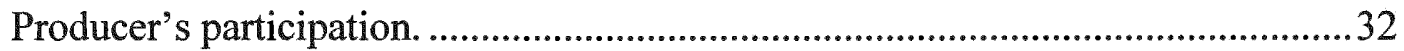

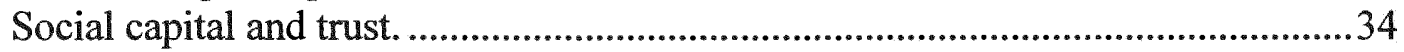

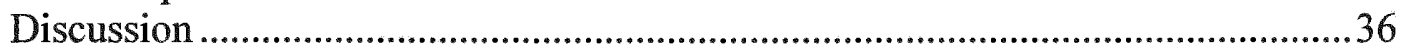

IV. SUSTAINABILITY AND ECONOMICS OF CHICLE HARVESTING...............38

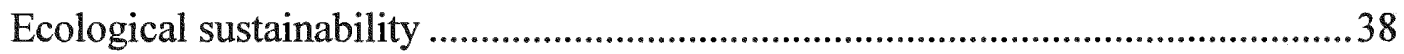

Valuation of chicle as a natural resource. .......................................................40

The Calculation of Extractive Value...................................................................43

Importance of chicle extraction for the local economy..........................................45

Estimated Potential production capacity in Quintana Roo ..................................50

The distribution of income from sales to producer .....................................................55

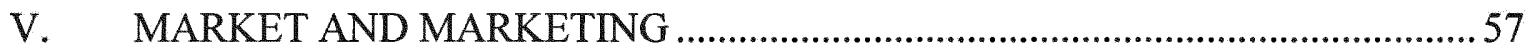

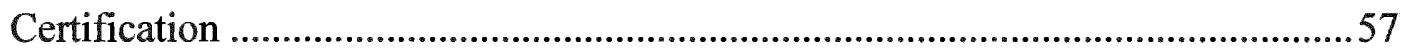

Commodity Chain and Control ............................................................................59

Control Production, Marketing and Distribution...................................................60

The chicle product and its consumers; certified chicle and non-certified chicle....62

The unique selling points of chewing gum and natural chicle ..................................64

Characteristics of consumers of organic food products ..........................................65

Consumers of organic food products in Europe....................................................65

Consumers of organic food products in the USA ..................................................69

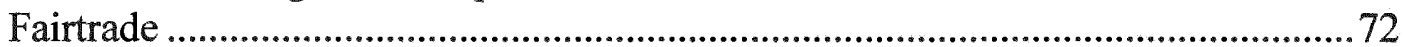

Organically certified products........................................................................ 74

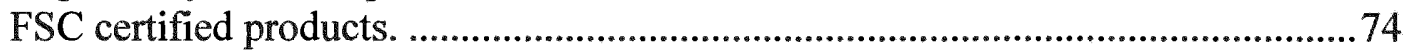

Marketing approach of current products ..............................................................

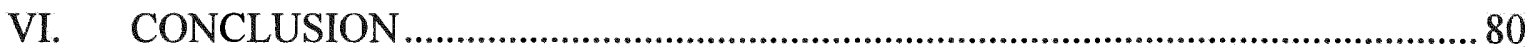

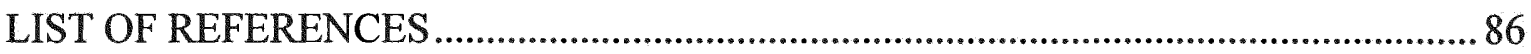




\section{LIST OF FIGURES}

FIGURE

PAGE

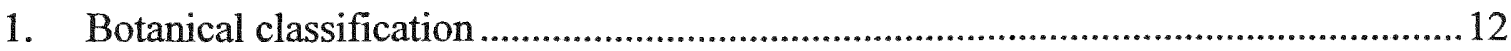

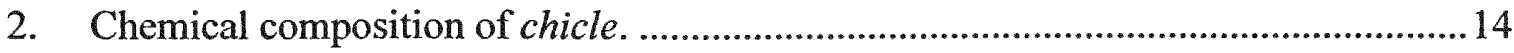

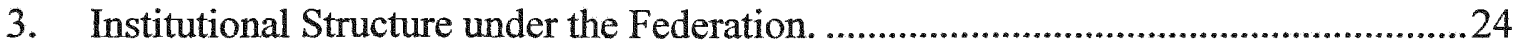

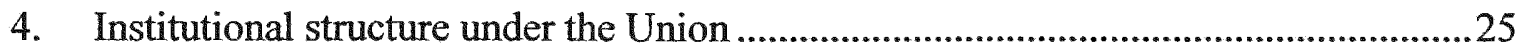

5. Summary of problems with the Federation...........................................................27

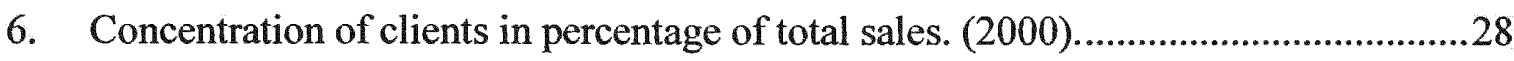

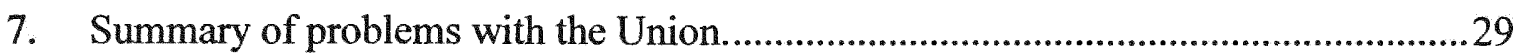

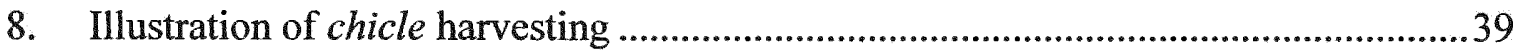

9. Chicle production of cooperatives of the Union.......................................................46

10. Mean cash incom earned from chicle extraction ........................................................49

11. Annual potential production capacity for Quintana Roo ..........................................51

12. Sales chicle of the cooperatives of the Union............................................................52

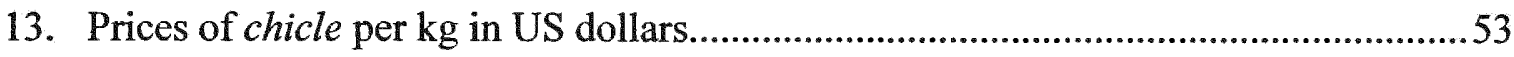

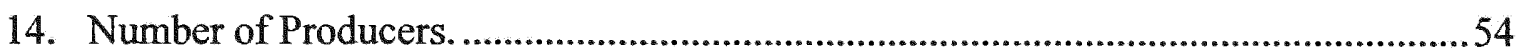

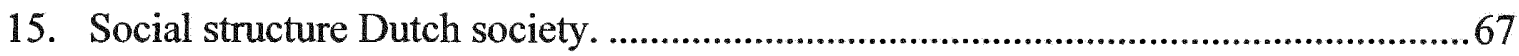

16. Texts on Packaging of Natural Gums Marketed in the US.........................................75 


\section{LITERATURE REVIEW}

This thesis examines the sustainability of the extraction of a non-timber forest product (NTFP) from the forests of Quintana Roo in the Yucatan Peninsula of Mexico. This necessarily involves the examination of the institutions which support the extraction, the ecological sustainability of the extraction, and the examination of marketing and markets that will assure demand and a fair price for a sustainable harvested product. The concept of sustainability and sustainable extraction goes back many years. At least since the 1930s sustained yield has been a goal resource management. The concept of sustained yield developed in the service of a utilitarian worldview in which nature was seen as a storehouse of raw materials and resources as merely commodities, and humans had dominion over nature. This is in sharp contrast with the definitions where the concern is with much more than one single commodity but with the environmental sustainability of an entire ecosystem. (Holling, 1998).

In the current worldwide system of capitalism a valid question is whether resources used in a capitalist system ever can be used in an ecological sustainable way. Some scholars like O'Connor argue that this is probably not possible. Capitalism is selfdestructing and in crisis; the world economy makes more people hungry, poor, and miserable every day; the masses of peasants and workers cannot be expected to endure the crisis indefinitely; and nature, however ecological sustainability is defined, is under attack everywhere. Sustainability is defined by environmentalists and ecological economists to mean: 'the use of only renewable resources and low or non-accumulating levels of pollution' (O'Connor, 1994). Ecologists define sustainability in terms of the maintenance of natural systems, wetlands, wilderness protection, and so on. But these 
definitions may have little or nothing to do with sustaining profitability. In fact, there is generally an inverse relation between ecological sustainability and short-term profit (O'Connor, 1994). What Hardin (1968) and other pessimistic believers have in common is a belief that human greed and shortsightedness almost always lead to overexploitation and often to the collapse of the resource. Such views serve as an antidote to the technological optimism deeply imbedded in the Western worldview that developed after the Middle Ages. The belief in unlimited material progress, that is achievable through economic growth and technological progress, is one of a suite of beliefs that characterize Western culture. This view generally assumes that the time stream of natural and human events is smooth and continuous and that the behavior of natural systems is narrow in range of variability and predictable. A product of this thinking is the concept of 'maximum sustained yield'. This concept treats natural resources as stocks, as discrete elements in space and time, predictable in isolation from other elements in the ecosystem. The idea of 'sustainable development', however, refers to a broader range of objectives. (Holling, 1998).

The Brundtland Commission defined sustainability as 'development that meets the needs of the present without compromising the ability of future generations to meet their own needs' (World Commission on Economic Development). Sustainability, as used here, is a process and includes ecological, social and economic dimensions. 'What has to be sustained and how can it be sustained ' must be addressed on a case by case basis. In this concept the future is not discounted. The view as presented by Berkes and Folke that social and ecological systems are linked, and that the delineation between social and natural systems is artificial and arbitrary, is rooted in deep ecology thinking that humans 
do not dominate nature but are part of it (Berkes, 1998). Whereas the criteria for ecological sustainability are relatively well known, there are no agreed upon criteria for economic and social/cultural sustainability. How do the social systems (property rights, land tenure, knowledge pertinent to environment and resources and worldview and ethics), economy and ecological systems relate? There is some evidence that society and the natural environment mutually modified one another over a period of time, and that local knowledge systems and property rights institutions became attuned to the resources used (Berkes, 1998).

The most common critique on the concept of 'sustainable development' is that the label is used as a veneer of environmental respectability on the process of continuing unsustainable practices. But this does not mean that we should reject the concept. Sustainable development is not a goal, not a condition to be attained on earth as we know it. Rather it is more like freedom and justice, a direction in which we strive. It is a process, not a final state (Holling, 1998). The mere rejection of the concept because there is no recipe nor theories that combine the social, economic and ecological elements nor certainty that future generations will meet their needs should not lead to ceasing in the way of sustainable thinking. Inherent to ecosystems and natural resource is the nonpredictability in time and space. What seems to be sustainable in our lifetime can be turn out to be a failure in future generations. This does not mean we should refrain from trying to manage resources sustainably.

In this thesis, I will be particularly concerned with sustainable management of the forests of Quintana Roo. The tropical forests of Quintana Roo in Mexico are part of the Central American forest that globally ranks fourth in biodiversity importance. 
The commercial exploitation of NTFPs embodies many of the challenges and natural tensions between economic development and conservation of nature.

One of the most discussed challenges is how to balance marketing and economic development with conservation of nature. In other words, can the extraction of a NTFP product like chicle both contribute to forest conservation and sustainable livelihoods at the same time?

Many studies on the ecological impacts of market-oriented extraction show negative impacts from commercial harvesting, usually leading to resource depletion. Other studies suggest that the ecological effects of commercial harvesting are not necessarily damaging. However, in the cases where NTFP harvesting has lower impacts, it may be due to the absence of a well-organized market for NTFPs (Neumann and Hirsch 2000). Other explanations for minor ecological impacts of extraction may lie in the institutional structure of harvesting and biological conditions of the NTFP. A well managed forest and the presence of strong forest institutions can contribute to commercialization with little negative ecological impact. Third party certification of sustainable harvesting practices has been promoted as an instrument to discourage overexploitation of NTFPs because it can give a market premium for more careful collecting practices. NTFPs may also be able to benefit from third party certification criteria that have been developed for fair trade issues and organic production. Fair trade certification requires evidence of the fair treatment of producers and fair prices for products, while organic production requires the absence of chemical inputs in the production process. There are also certification schemes for sustainable forest management practices. 
NTFPs play a significant role in providing subsistence and cash income to a large part of the world's population, especially to the poorest households in rural communities. Unfortunately, the marketing of NTFPs does not always lead to increased income for these households. On the contrary, many studies show that NTFP commercialization can perpetuate poverty because of low market prices for significant inputs of labor resulting in economically unsustainable practices.

A second major challenge in commercialization of NTFPs is that the institutional structure often determines the welfare of households who depend upon the NTFPs. A typical example of labor exploitation in extractive markets is the aviamento system in Brazilian rubber, a form of debt-peonage. Extractors are trapped in a cycle of debt that keeps them impoverished. The whole institutional structure of labor organization, property rights, government regulation and control over the extraction process is crucial in whether commercialization of NTFP will perpetuate poverty or contribute to economic development.

In the case of Mexico, since the 1970s social movements for reform and democracy have been making the transition from confrontational opposition to the construction of positive policy alternatives. In the process, a new sense of citizenship has emerged with a political push for accountable government. Social movements that had previously abstained from electoral politics began to get involved in the often frustrating process of gradually widening small openings in the state at both the local and national levels (Fox, 1992). Mexican history has long been marked by political conflicts between central and local authorities. In theory, the United States of Mexico is a federation, and state governors have long considered themselves to be the sovereign authority within 
their domains. However, the president can name candidates and can depose governors. In Mexico, as elsewhere, for most people, most of the time, politics is local. Local means not only the state level (Quintana Roo) but also the municipal level and the level of ejidos. Ejidos are the principal form of organization in rural Mexico. They are collective landholdings, where agricultural plots may be privately appropriated but where pasture and forest resources may be held in common. Thus, the management of forest lands on ejidos in Mexico is an example of a common property resource management regime (Ostrom, 1990). Mexico today has more forests under active community administration than any other country in the world (Bray, 1995). As a result of land distribution beginning with the Mexican Revolution, some $80 \%$ of the nation's forests are formally in the hands of these collective communities called ejidos and agrarian communities. Ejido forest lands may be exploited communally and profits are divided among the ejidatarios, the members of the ejido. Access to natural resources is determined by the ejido rules. The World Bank defines these community-based organizations as the 'third sector' as expressions of emergent civil society (Fox, 1997). It is important to recognize the political relevance of these community-based actors. In the past inter-community or ejido organizations have often been excluded from development projects and decision-making. By contrast, community forestry in Quintana Roo is often used as an example of a successful inclusion of community-based economic development. The extent to which producers and collectors participate in decision making in the institutional structure may greatly influence their success in benefiting from commercialization of the NTFP.

Another element in the institutional structure influencing the success of NTFP commercialization is the amount of social capital and trust. In the literature social capital 
is defined in different ways. Some define it as the stock of norms of reciprocity and networks of civic engagement that helps explain how citizens overcome the obstacles to collective action (Fox, 1996). Along the same lines is the definition of social capital as the shared knowledge, understandings, norms, rules, and expectations about patterns of interactions that groups of individuals bring to a recurrent activity (Ostrom, 1990). Social capital takes many forms. In this case it is specifically interesting to look at the social capital within the group of collectors of NTFPs and within the institutional structure surrounding them. From an organization theory perspective, social capital is defined as tacit knowledge, collection of networks, aggregation of reputation and styles. Trust is an important component of social capital. Trust is based on reputation and reputation is acquired on the basis of consistent behavior over time, regarding which consistency has value and is the product of human actions. As a society economically develops, its social capital must adapt as well, allowing the interpersonal networks to be partially replaced with the formal institutions of a market-based economy (Stiglitz, 2000).

The third challenge discussed here influencing the sustainable commercialization of NTFPs is marketing and markets. Marketing networks can determine whether the commercialization of NTFP is exploitative and monopolistic or beneficial for producers. Much of the research that focuses on marketing networks reveals dynamism in the relationship between producers and intermediaries further down the line. These relationships are not fixed, but can change over time. One of the most common forms of traditional relationships is that of patron and client, sometimes associated with debtpeonage. A number of factors keep collectors in a relatively powerless position. Collectors lack sufficient capital to buy a motor boat to transport their produce to market. 
This forces a reliance on traders who have a monopoly of transport and can therefore fix prices well below market rates. In remote forest communities, intermediaries may also have a monopoly on information. Many collectors are at a disadvantage in relations to traders because they do not have access to current price information from distant markets. Often producers encounter difficulties attempting to market their products directly. Lack of access to credit, transportation, information and storage facilities combine to keep producers at a great disadvantage in the marketplace. These conditions provide plenty of opportunities for intermediaries to position themselves as almost unavoidable links in the marketing chain (Neumann and Hirsch, 2000). The most common problems rooted in the marketing network are exploitation of producers, excessive bureaucratization, inappropriate price-fixing among various marketing institutions and increased opportunities for rent-seeking for agents of government cooperatives by cheating.

Despite some reports of success, rainforest harvest of NTFPs has been criticized. The market demand for rainforest NTFPs is driven to a large degree by a faddish interest in 'saving the rainforest' in the consumer countries of the North. Exposing NTFP collectors to volatile international markets for non-essential luxury goods, it has been suggested, will make the collectors subject to the same social and economic upheavals of previous boom-and-bust cycles. Other critical remarks address the issue that possibilities for widespread implementation of commercialization of NTFPs is limited to those communities with a marketable product and connection to transport links. And often these projects are financed by loans which maintains a sort of debt bondage relation (Neumann, 2000). 
In the literature on NTFPs many other aspects influencing the success and failure of commercialization of NTFPs are addressed like socio-political aspects as gender, poverty and wealth distribution and management issues.

The purpose of this research is to analyze the problems and limitations of chicle commercialization in Quintana Roo. The analysis will be primarily focused on the institutional structure, sustainability of the activity and marketing and markets. I will argue that those factors may limit or boost the commercialization of chicle. Aspects like gender, poverty and wealth distribution, management and economic considerations are only discussed in passing. The central question is: "How the institutional factors, sustainability aspects, marketing and green markets condition the potential for chicle commercialization to increase incomes and to contribute to tropical forest preservation in Quintana Roo?"

The research is based on examination of available primary and secondary literature. Since relatively little has been written about these particular aspects of chicle harvesting, part of the data was collected in Quintana Roo, Mexico. I spent six weeks in Quintana Roo in the summer of 2001. During that time I conducted unstructured and semi-structured interviews with relevant actors in the chicle activity. About 40 interviews were held with representatives in the whole production and distribution chain; producers (chicleros), buyers, producer's organizations, government, exporters, environmental experts, marketing experts and sales persons. The objective of the unstructured interviews was to get complete insight in the institutional aspects of the production and sales of chicle and to identify specific problems with sustainability, marketing and markets. 
Interviews were held in Chetumal, the ejido of Noh-Bec and in Felipe Carillo Puerto in Quintana Roo, Mexico. At the library of the University of Quintana Roo in Chetumal I studied documentation that was not available in the United States because of its local nature.

The reminder of this thesis will be organized in the following way. First the basic elements of the chicle production process, historical facts and other relevant background information of the production of chicle are given in Chapter 2. Then, Chapter 3 discusses institutional issues. Problems with old and current organizations that represent the producers are analyzed in this chapter. Access to the natural resource is discussed in the paragraph on property and user rights. Producer's participation and social capital is discussed in the last paragraphs of this chapter. Chapter 4 addresses sustainability aspects of the harvesting. Ecological and economical sustainability of the chicle activity are discussed. In Chapter 5 aspects of marketing and green markets are reviewed. The first paragraph reviews different certification schemes. Control over the commodity chain is discussed in the second paragraph. Potential consumer groups and their characteristics are discussed and the marketing messages used by the natural chewing gum marketers are reviewed in the last paragraphs of this chapter. Conclusions are summarized in Chapter 6. 


\section{CHICLE; ECOLOGICAL, TECHNICAL AND HISTORICAL FACTS.}

Chicle is harvested from the tree Manilkara Zapota. The family Sapoteceae is a medium-sized family of pantropical forest trees and shrubs containing about 450 species in the Neotropics, distributed from the southern United States through Mexico, Central America and the West Indies, and South America to Paraguay, Uruguay and Chile. It is predominantly a family found in lowland wet forest, though some genera are also well represented in the savanna of the Guyana Highland and in semi-arid zones of Central America and the West Indies. The family provides many economically important products: latex, durable timber, and many edible fruits. In Figure 1. the botanical classification of chicozapote is summarized. The genus Manilkara occurs in Africa, Asia and the Pacific, as well as the Neotropics, from Mexico to South Brazil including the Caribbean Islands. The genus is particularly well represented in lowland wet forest and dry forest over limestone (Yucatán and Caribbean Islands) and beach forest (Alcorn, 1994).

\section{Botanical classification}

\begin{tabular}{|l|l|}
\hline Family & Sapoteceae \\
\hline Genus & Manilkara \\
\hline Specie & Zapota \\
\hline Botanical Name & Manilkara Zapota L. \\
\hline
\end{tabular}




\begin{tabular}{|l|l|}
\hline Common Names & $\begin{array}{l}\text { Chicozapote, sapodilla, } \\
\text { yicazapotl, yuenda-xiña, } \\
\text { zapote de abejas, zapote } \\
\text { morado, zapotillo }\end{array}$ \\
\hline
\end{tabular}

In Quintana Roo the species is abundant and often associated with other species like Alseis yucatanensis (Tabaquillo), Coccolabo spicata (Boop), Swartzia Cubensis (Katalox), Vitex gaumeri (Ya'axnik) (Mayan names are in parentheses). This type of vegetation is characteristic of the Yucatán Península. Forests where chicozapote is present are characterized by a precipitation of 1500 to $1000 \mathrm{~mm}$ per year (Ramírez Aguilar, 1992).

The species Manilkara Zapota is native to Belize, Guatemala and Mexico, with scattered native populations on the Atlantic coast of Nicaragua, but has been cultivated pantropically. Consequently, it is presently found throughout Central America and the Caribbean islands, in gardens and semi natural vegetation throughout much of South America. Many local uses and common names are associated with the species. Manilkara Zapota is a tree that can reach over $45 \mathrm{~m}$ in height, and over $125 \mathrm{~cm}$ in diameter. Mature trees are evergreen or semi-deciduous and have spirally arranged, simple leaves clustered at branch tips. The cream-colored flowers are bisexual and sympetalous, with petals alternating with petal-like staminodia. They are axillary, solitary, and occur densely packed at branch terminals. The brown, scaly, rough skinned fruit is about $4 \mathrm{~cm}$ in diameter and is extremely sweet. The fruit usually contains 2 to 5 flat, shiny, dark-brown seeds. The bark is usually gray and furrowed on younger trees, becoming very thick, deeply fissured, or checked with age. The slash (inner bark) is distinctly pink or 
occasionally white. The tree's canopy is usually very dense and the sympodial branch form is immediately distinguished. (Alcorn, 1994)

\section{Technical facts of chicle}

Because Mexican chicle contains about 35\% water, evaporation through cooking of the resin is an important part of the process. In Figure 2 the chemical composition of chicle is summarized.

\section{Chemical composition of chicle.}

\begin{tabular}{|l|l|}
\hline Element & Percentage \\
\hline Resin (acetone, soluble) & 40,0 \\
\hline Guta (carbon and hydrates) & 17,4 \\
\hline Proteins & 0,6 \\
\hline Mineral substances (ashes) & 4,7 \\
\hline Water & 35 \\
\hline Sand and other substances & 2,3 \\
\hline
\end{tabular}

The most important ingredient is the resin (chicle) that is collected from the tree. After collection the resin is cooked. During the cooking process the water content declines substantially until a sample consists of almost $65 \%$ of resin (Heuer, 1945). The cooking process is very important because the price of chicle depends upon the percentage of humidity of the marqueta. Then after cooking the chicle is poured into 
standard wooden molds and put to dry. Released from its mold the result is a marqueta. A marqueta is a semi-dried block of chicle weighing about $10 \mathrm{~kg}$. Due to the extraction of water the weight of harvested chicle declines. In storage where the final drying takes place further decline in weight takes place.

The end product in this production stage is the dried chicle in marquetas, ready to be used in the industrial process of gum-base and later chewing gum production.

At the time of delivery to the buyers, the chicle is weighed and its water contents is determined. To measure water content, four random samples of $50 \mathrm{~g}$ per ton of chicle are taken. Each sample is dissolved in $200 \mathrm{~cm} 3$ of xylol $(\mathrm{C} 6 \mathrm{H} 4(\mathrm{CH} 3) 2)$. The four solutions are distilled separately and the volume of water thus obtained is multiplied by two to obtain a percentage value. A mean percentage value is obtained from the four samples. Prices of chicle are determined on the basis of a standard humidity of $22 \%$. The price paid to the contractor increases as the water content decreases and vice versa (Barrera de Jorgenson, 1993).

The chicle in marqueta is the raw material input for the gum-base factories. Gumbase is the main ingredient for chewing gum production. It gives chewing gum its distinctive quality, binds all ingredients together and creates a smooth, soft texture. The gum-base factories sell the gum-base to chewing gum and other candy companies where it is used to produce various consumer products like licorice, chewing-gum and other candies.

Anthropological background

Manilkara Zapota is found in the Mexican states of Tamaulipas, México (D.F.), Veracruz, Oaxaca, Chiapas, Tabasco, Campeche, Yucatán and Quintana Roo. It also 
occurs in Belize and the Petén of Guatemala, and has been recorded from isolated locations along the Atlantic coast of Nicaragua. As a result of this broad distribution, chicle is thought to have been used by both the Aztec and the Maya culture. However, almost no information regarding how the plant was used by these peoples is documented. In the more recent past, chicle has had the distinction of being one of the most economically and politically important species in Mesoamerica. Along with commercial harvesting, there arose an interest in knowing more about the characteristics of the tree. For example, the Chicle Development Company (CDC) was established in the early 1900 's, with the expressed intent of conducting research that would enable plantation production, reduce mortality and increase yields and allow for sustainable production of chicle (Hendrickson, 1976). Other research has been done on the ideal harvesting time and the relation between yields and weather. Under the CDC most of the investigations were done by Karling (1934). Karling revealed that changes in stem diameter were directly correlated with relative humidity: high humidity signifies an increase; low humidity, a decrease in diameter. This is the main reason why harvesting takes place during the rainy season and starts when the rains actually have started to fall. Karling concluded that the chicle tree reaches its greatest diurnal diameter at about 6 a.m. and is therefore likely to show greatest yield at this time

Alcorn (1994) points out that perhaps the most long-standing question about the chicle tree and its place in the forests of Mesoamerica, concerns the relationship between the ancient Mayans and the chicle tree. It is not really known whether that relationship influenced the high density of this tree in the contemporary forests. Some researchers are convinced that the Maya cared for, protected, and even cultivated the chicle tree for fruit, 
gum and timber. Unfortunately, no research exists to substantiate the notion that today's high density of Manilkara zapota is anthropogenic. (Alcorn, 1994).

In Mexico today most of the chicle is harvested in the Southeastern part of the country, principally in Quintana Roo and Campeche. In other parts of Mexico like the states of Tabasco, Veracruz and Chiapas some chicle activity takes place but on a minor scale.

\section{Historical development of the chicle indusiry}

The use of chicle dates back to the Maya and Aztecs who chewed gum to quench thirst and used it for medicinal and religious purposes. Chewing chicle was also popular among the military from Veracruz in the nineteenth century. Evidence of this is the fact that it was the famous general Antonio López de Santa Anna (1794-1876), a native of Veracruz, who first introduced the gum to the United States. Santa Anna was an important political and military leader. During an exile in Staten Island in the United States, in one of numerous periods when he was in and out of the presidency and the country, Santa Anna brought with him a large clump of chicle for chewing. When he returned to Mexico, he left the chunk of gum with his interpreter and secretary, James Adams. Adams made several unsuccessful attempts to vulcanize the gum for use as a rubber substitute. After further experimentation, Adams discovered that the gum was easy to chew and blended well with sugar, corn syrup, flavorings, licorice and peppermint. Within a few years he founded the Adams Chewing Gum Company, the beginning of the multi-million dollar chewing-gum industry. As a result of this emerging industry, chicle exports from Mexico to the United States increased from 4.2 tons in $1885-1886$ to 1,633 tons in $1895-1896$. The two World Wars of the 20th century created 
booms for the industry. Consumers were led to believe that chewing gum facilitated digestion, mitigated thirst, and helped relieve nervous tension- even during combat. Thus the U.S. Defense Department authorized the supply of chewing gum to the troops. American soldiers not only consumed large quantities of gum but also helped spread the popularity of chewing gum to other countries.

After World War II the chewing gum industry continued to thrive, but the demand for raw chicle dwindled, the result of the discovery of petroleum-based substitutes, which begun to replace chicle gum. In addition, chicozapote trees had become depleted in several areas, making the supply of chicle to the chewing gum industry less reliable and more costly. An unreliable supply of natural gum and a readily available supply of less expensive substitutes accelerated the switch from natural gum to petroleum-based substitutes causing a severe decline in demand for natural gum. 


\section{INSTITUTIONAL ANALYSIS.}

In this section the institutional aspects of chicle and its challenges for successful commercialization is analyzed. The main question of this chapter is: 'How do the social systems (property rights, land tenure, knowledge pertinent to environment and resources), economy and ecological systems relate?' To tackle this question the institutional history and current institutional structure are reviewed. The management of the forest has changed over time, influencing the chicle economy. Representative producer's organizations are discussed in order to discover problems and constraints for

producers in the further development of the chicle activity. The problems, constraints and opportunities resulting from the institutional structure are summarized in the second section of this chapter. Then the property and user rights are discussed. Access to the natural resource determines who may profit. Producers' participation is discussed in the last section and is aimed at analyzing the role of producers in the decision making process. The results of the analysis are wrapped up in the discussion in the end of this chapter.

The institutional history and current situation.

The forest exploitation in Quintana Roo has undergone dramatic changes from exploitative-concessions, government managed and unsustainable to community owned, community managed and sustainable forestry (Galetti, 1998). The principal goal of this change was to halt forest destruction by making the rational use of forestry resources a secure and attractive source of income for the local population. Secondly, the forest owners are the social actors most interested in the conservation of the forest for economic 
reasons (Galetti, 1998). This is based upon this simple premise: forest owners and managers have a vested interest in maintaining the forest if they receive tangible and secure economic returns from it.

In reaction to the concession-based approach to forest extraction for years, an alternative was created; the Plan Piloto Forestal ('Forestry pilot plan'). This plan is a product of an ending long-term concession, political space for a shift in approach and governmental financial support. The primary goal of the Plan Piloto Forestal is to empower ejido residents and increase the economic returns they receive from the forest. Forest inventories were made and permanent forest areas were designated under the Plan Piloto Forestal. Permanent Forest Areas are areas of forest that must be designated by each ejido participating in the plan, for communal management exclusively for forestry production. Within this permanent forest area long term and annual harvesting blocks are designated as well as extraction quota per timber species. Agriculture activities take place outside the permanent forest areas, usually on individual pieces of land (milpa). One of the key social factors is the manner in which resource users are collectively organized to make decisions about production and, perhaps more important, the distribution of revenues. The Plan Piloto Forestal was built on the ejido foundation with its decades-old approach to communal decision making. Rather than attempt to replace this with a structure organized expressly for forest production, the plan worked within the ejido structure, with the participation of virtually all ejidatarios guaranteed and present from the outset (Kiernan).

The sustainable community forestry in Quintana Roo is often cited as a successful example of sustainable development. It is based on a simple premise: forest owners and 
managers have a vested interest in maintaining the forest if they receive tangible and secure economic returns from it. Though this logic seems both simple and compelling, there are few examples of successful natural forest management in either the tropics or temperate regions. Further, we poorly understand to what degree biodiversity is important for long-term forest productivity, or how biodiversity may be affected by natural forest management methods. The Plan Piloto Forestal formulated an alternative approach to the traditional concession-based forest. Implementation caused that the ejidos connected to the Plan Piloto Forestal converted Quintana Roo's forest to a more sustainable and community-based managed forest. The Plan Piloto Forestal seeks to intensify the use of the Permanent Forested Areas by developing or accessing markets for new forest products. The three most important forest products for the ejidos that implemented the Plan Piloto Forestal are high-value hardwood timbers (mahogany and cedar), all other soft-wood and hardwood timbers and chicle. Chicle is relatively a newcomer under the Plan Piloto Forestal, which until recently had targeted only timber (Kiernan). Although chicle is formally not organized under the Plan Piloto Forestal but instead under the Plan Piloto Chiclero (the Union), both 'Plans' are closely connected. Under this approach of the two plans, the ejidos working under their umbrella have developed one of the most promising efforts under way anywhere in the tropics to produce a system of forest production that is both socio-economically and ecologically sustainable. Some 6,600 rural families are participating in a new form of rural development based on the wise use of forest resources. There are hurdles and risks ahead. For example, only two species (mahogany and cedar) currently have markets strong enough to generate significant revenues providing a weak foundation on which to base 
management in species-rich tropical forests like that of Quintana Roo. To date, the ejidatarios' livelihood almost entirely derived from timber and chicle. This illustrates the importance of the chicle activity in the contribution to sustainable forestry.

Within the forestry institutional structure the organization of the chicle activity also has changed over time. Before 1930 the chicle exploitation was completely controlled by foreign contractors. Chicleros were contracted as temporary, seasonal wage laborers. This changed when the government took more control in the early 1930 s. Most of the foreign held concessions were cancelled and forested areas were granted to the ejidos during President Lázaro Cardenas' (1934-1940) land reform.

Complementary to the agrarian and land reform was the creation of government protected chicle cooperatives, which helped to organize and control the chicle industry. Most of these large forestry ejidos and chicle cooperatives still exist and function today (Konrad, 1986).

By 1939,46 cooperatives with a total of 2,394 chicleros were established. The cooperatives were regulated by law (Ley general de las sociedades) and had to form part of a Federation of Cooperatives (the Federation) which in turn should form part of the National Confederation of Cooperatives. The Federation was responsible for marketing and shipping, purchasing and selling equipment and supplies necessary for production and representing and protecting the general interests of the organization. Each participating cooperative of chicleros had to contribute at least $10 \%$ of its income to the Federation and maintain a trust fund of at least $25 \%$ of its income as a social security fund (Barrera de Jorgenson, 1993). That social security covered medical expenses in case 
of job-related illness or injury. It was these benefits which attracted a large majority of ejidatarios to work in this economic activity (Barrera de Jorgenson, 1993).

Until 1978 the Federation was highly politicized and there was no free election of its president but instead the governor of the state of Quintana Roo appointed him. After the introduction of democratic election in 1978 this process became more democratic.

The government also controlled the sales of chicle. The entire chicle production was sold through the export company Impulsadora y Exportadora (IMPEXNAL), a branch of the National Foreign Trade Bank (Banco Nacional de Comercio Exterior). This monopoly was created through a government tax law, exempting IMPEXNAL from paying export taxes. For the producers it was impossible to influence the prices and most revenues were accumulated at IMPEXNAL resulting in continued unequal distribution of revenues.

It turned out that the institutional structure (Figure 3) was not beneficial at all in providing benefits for the chicle producers. The cooperatives represent the organization of chicleros on the ejido level. Those cooperatives are affiliated to the regional sociedad de productores forestales on the state level. They were all related to and organized under the Federation. 


\section{Institutional Structure under the Federation.}

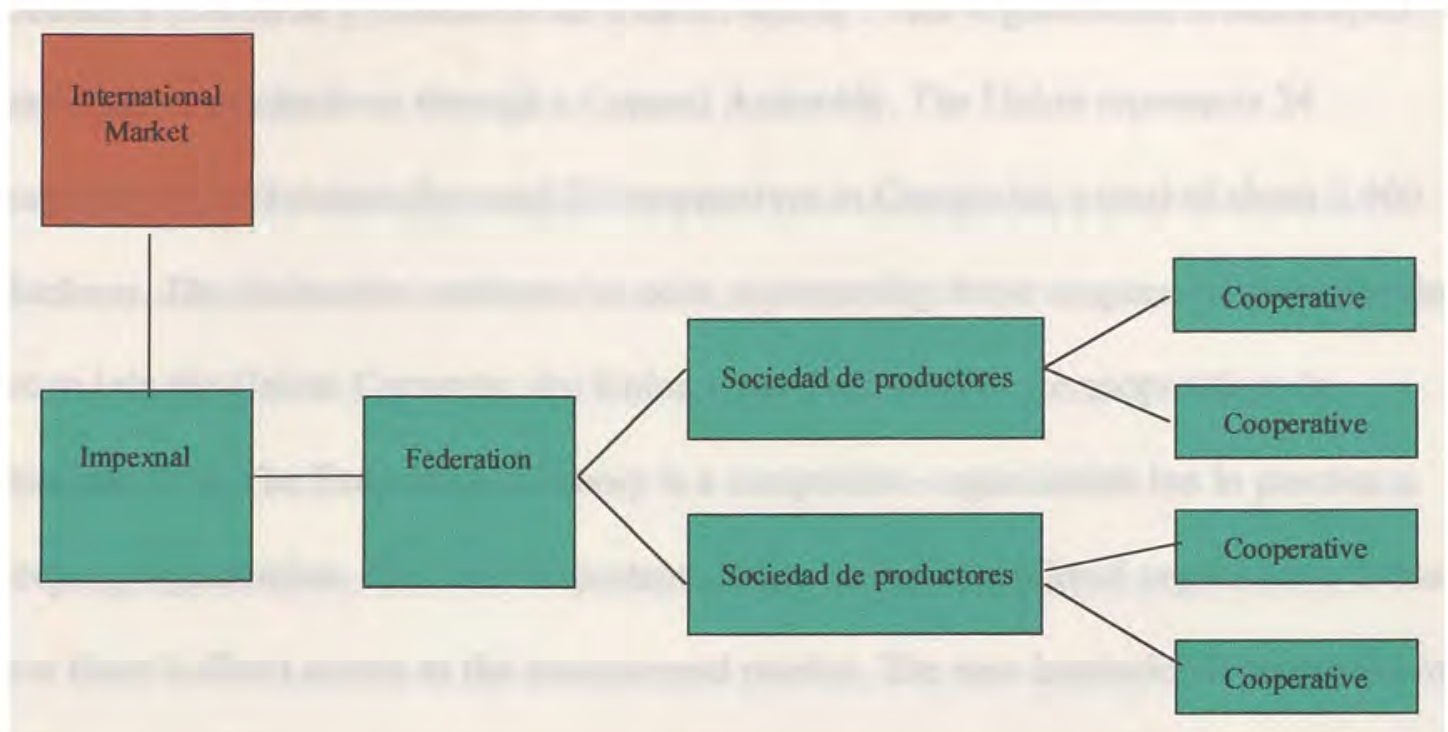

The Federation of Cooperatives in Quintana Roo became financially unstable during the 1970s with poor management and erratic demand for chicle weakening the financial status of the organization. (Barrera de Jorgenson, 1993). The administrative costs of the Federation had reached $26 \%$ of total sales and the pawning system kept the chicleros constantly in debt because it is a system that is based on loans. To secure the loan the chicleros must pawn the chicle to the Federation. Consequently, in practice a chiclero never owns anything. To be able to produce and support the family in the harvest season the Federation gives out a loan. The annual harvest of chicle is used to pay back the loan. Usually there are no additional earnings (Galletti, 2001).

The management problems as summarized in figure 6 , finally resulted in organizational and financial chaos within the Federation. This troubled situation led to the establishment of a rival organization and marketing effort in 1994, the Plan Piloto Chiclero (PPC) a new model for the productive and commercial organization of the chicle activity.(Natural, 2000). 
The PPC initiative led to the founding in 1998 of the Union of Natural Chicle Producers (Unión de Productores de Chicle Natura) . This organization is based upon participation of chicleros through a General Assembly. The Union represents 24 cooperatives in Quintana Roo and 22 cooperatives in Campeche, a total of about 2,400 chicleros. The Federation continues to exist, representing those cooperatives that decided not to join the Union. Currently, the Union represents most of the cooperatives in Quintana Roo. The Federation in theory is a competitive organization but in practice a sleeping organization. The most important change in the institutional organization is that now there is direct access to the international market. The new institutional arrangement is presented in Figure 4 below.

\section{Institutional structure under the Union}

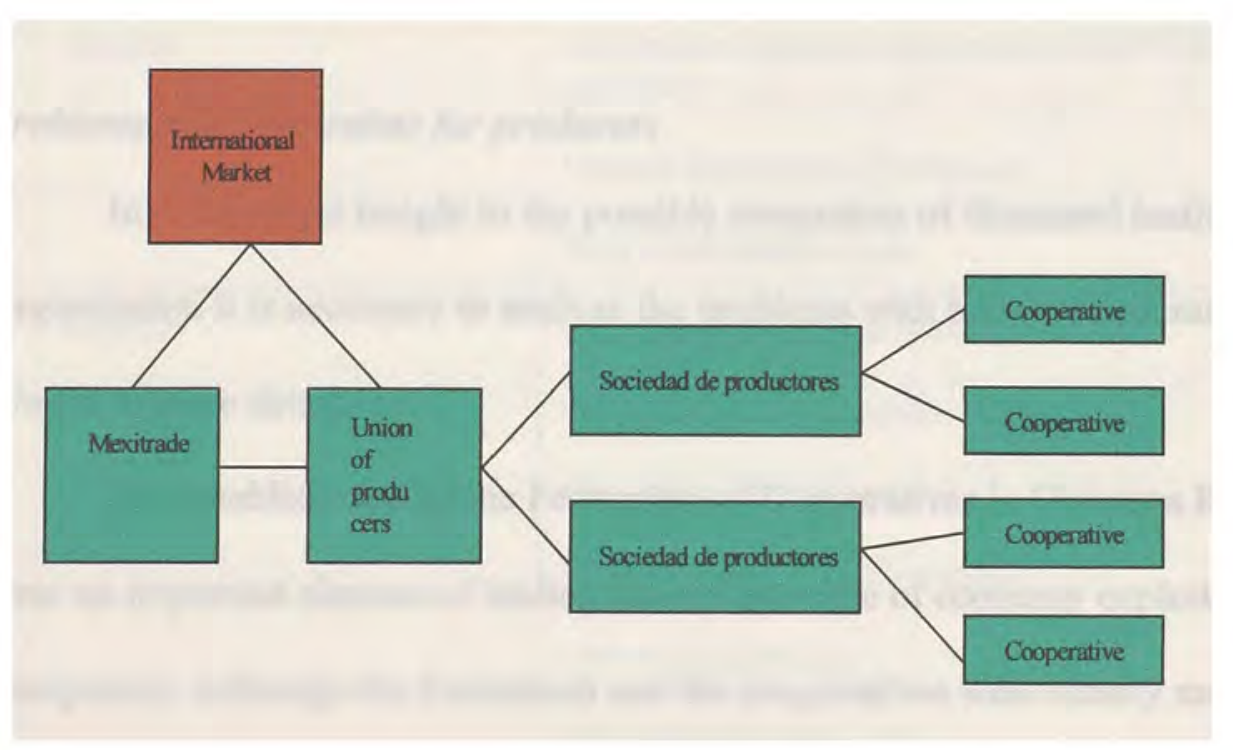


The main objective of the Union is to bring the chicle activity under the control of the ejidos in order to generate more revenues for the chicleros. In the business plan these objectives are stated:

- Development and strengthening of the new productive and financial structure after the establishment of the integration of cooperatives forming the Fondo Chiclero (the chiclero fund). This fund is intended to cover production costs, social security and healthcare for the chicleros.

- Establish the integration of the producers and professionals participating in the cooperative enterprise (empresa social) represented by the Union.

- Improve experiments in industrial processing of natural gum.

- Develop a plan for the commercial promoting of natural gum and other (new) end products or trial products (Unión de Productores de Chicle Natural).

\section{Problems and Constraints for producers}

In order to get insight in the possible constraints of discussed institutional organization it is necessary to analyze the problems with both the Federation and the Union in more detail.

The establishment of the Federation of Cooperatives in Quintana Roo was at that time an important element of ending the enclave type of economy exploited by foreign companies. Although the Federation and the cooperatives were clearly meant to hand over the control to the local people of Quintana Roo, the owners of the resources, the organization was not democratically operated and became highly politicized. Instead of foreign companies during the concession time, now the government controlled chicle 
exploitation; there was no real participation of producers in decision making. It was not until 1978 that the Federation of Cooperatives elected its president in a free and democratic way improving participation of producers.

The two layers of intermediaries and the monopoly on exports are the main causes that direct contact between the chicleros, their cooperatives and the market have never been established. This lack of market contact impeded the development of new products and prevented vertical integration of the industrial process toward the local production of a value-added product.

In figure 5 below, a summary of problems with the Federation is presented.

\section{Summary of problems with the Federation.}

\begin{tabular}{|l|l|}
\hline Institutional level & Problem \\
\hline National & $\begin{array}{l}\text { Government supported monopoly of IMPEXNAL, tax } \\
\text { exemption } \\
\text { Unequal distribution of revenues } \\
\text { High administration costs }\end{array}$ \\
\hline Local & $\begin{array}{l}\text { High politization of the Federation } \\
\text { Lack of representation } \\
\text { Unequal distribution of revenues } \\
\text { Lack of transparency } \\
\text { High administration costs } \\
\text { No upscaling of production process toward more value added } \\
\text { product. }\end{array}$ \\
\hline Low participation of producers \\
\hline
\end{tabular}




\begin{tabular}{|l|l|}
\hline Low revenues \\
Indebtness \\
Lack of trust in intermediary organization \\
$\begin{array}{l}\text { No upscaling of production process toward more value added } \\
\text { product }\end{array}$ \\
\hline
\end{tabular}

\section{Problems with the Union}

The Union was founded as a reaction to the malfunctioning of the Federation in order to solve most of the aforementioned problems. Functioning for about three years now, there have been some important changes. The Union is now directly dealing with the market. This is considered as a major improvement because the pricing can be negotiated through the Union and is no longer determined by one sole exporter. However, in these difficult times of low demand there is still not much negotiation space. The monopoly of IMPEXNAL had disappeared formally but Mexitrade, a former semi-government company, followed in its footsteps and has most of the important market contacts resulting in a dominant market position. Because Mexitrade is involved in many different types of business with international clients, those clients buying chicle do not buy directly from the Union but seem to prefer to buy through Mexitrade instead. Figure 6 shows that Mexitrade is the most important client of the Union, buying about $50 \%$ of its production. 
6. Concentration of clients in percentage of total sales. (2000)(Aldrete, 2001).

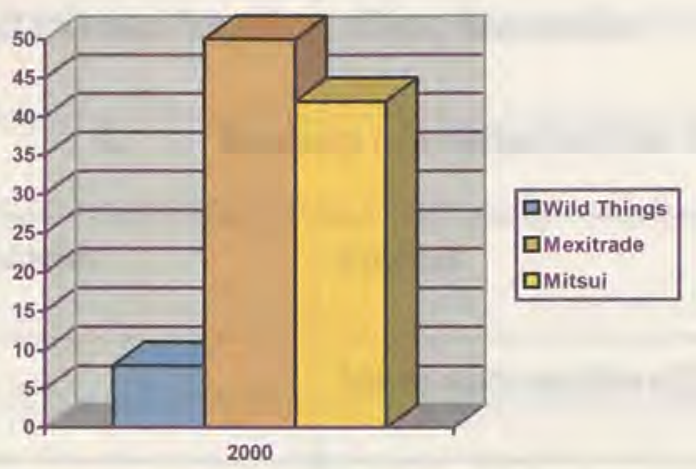

Figure 6 shows the dependency of sales to Mexitrade. Mexitrade pays the lowest price compared to the other buyers. Of total sales only $7 \%$ is sold to the US market and $43 \%$ is sold to Japan through Mitsui.

The most common critique heard from interviewed producers was that the Union favors some cooperatives above others and unequally distributes the yearly scarce production of chicle. Producers feel that they not really can influence decision-making and they consider the financial organization as not transparent. Complaints were heard about a lack of information on markets and pricing. It must be noted that the Union is relatively new and started from the chaotic inheritance left by the Federation.

Another factor impeding the autonomous development of the Union is the lack of demand. Less then $50 \%$ of the production capacity of the cooperatives is used and it is hard to find an alternative for the dependency on Mexitrade under current market conditions of low demand.

With respect to the financial aspect there have been some problems with quality resulting in the situation that Mexitrade did not pay the Union and chicleros remained without income. This has deteriorated trust and disturbed the relation between chicleros, 
the Union and Mexitrade. The conflict about the fact that Mexitrade did not pay for a substantial part of the production is ongoing and characterizes the bad relationship between the Union and its most important client, Mexitrade.

7. Summary of problems with the Union.

\begin{tabular}{|l|l|}
\hline Institutional level & Problem \\
\hline National & Monopolistic position of Mexitrade \\
\hline Lack of representation \\
Local & $\begin{array}{l}\text { No upscaling of production process } \\
\text { toward more value added product (but } \\
\text { plans in progress) }\end{array}$ \\
\hline $\begin{array}{l}\text { Low participation of producers } \\
\text { Lack of trust in intermediary organization }\end{array}$ \\
toward more value added product \\
\hline
\end{tabular}


The growing independence of Mexitrade and the search for the Union's own clients is a right step in the process of lowering of intermediary costs and in providing more revenues for producers. To make a big leap forward in generating more local revenues for producers it is necessary to produce a more value-added product at the local level.

The increased independence of Mexitrade contributes to the solving of the unequal distribution of revenues. Although still in small quantities the direct sales to other companies lower the intermediary costs and contribute to an improvement of revenues for producers. The Union is trying to expand direct sales to diversified clients in promising markets and is developing plans for the local production of value added end product. All these developments should lead to improvements in benefits for producers side in the long run.

\section{Property and User Rights}

Chicle is harvested from the chicozapote tree in the rainforest. Access to the resource is crucial in controlling the production of chicle. This paragraph describes the way access to the natural resource chicle is regulated and describes the customary arrangements around the partitioning of the forest between chicleros.

The access to chicle from the chicozapote tree differs from other forest activities like other types of natural resources like timber, palm leaves and other non timber forest products. As mentioned earlier, except for chicle all the other forestry activities are considered to be communal. The revenues of the communal forest activities are equally divided among all ejidatarios. Chicle, however, is not communal work but is an 
individual activity. Chicleros go out in the forest by themselves or in small groups, they harvest according their ability or desire and also obtain revenues for themselves according to the weight of the harvested latex. In order to obtain this 'exploitation right' from the ejido, the Cooperative of the chicleros pay an access fee (derecho de monte) (Leyva Martinez, 2001). Chicleros are free to collect chicle anywhere in their ejido and are not restricted as to tree size or the number of chicozapote they tap (Barrera de Jorgenson, 1993). Voluntary cooperation and mutual trust are strong among chicleros. They speak proudly of their camaraderie and respect for territories of their fellow tappers while working in the forest and help each other in finding good patches of trees. Once a chiclero located a good patch that patch is considered 'his' and is not intruded upon by fellow chicleros (Dugelby, 1998). Usually chicleros have so much experience that they know every square meter of the forested area of their ejido (el monte), and already know at the beginning of the season which area they will harvest. The partitioning of the forest among chicleros is based upon customary agreements. The access to the resource (chicozapote) is somewhat formalized through the ejidal system and the payment of access fee (derecho de monte). The high level of social capital among the chicleros makes this system work. They have an extremely high level of knowledge of the forest and of the resource. The strong relation and trust among chicleros make the formally unregulated access to the resource function well. Problems occur when there is a high number of migrating laborers that start to collect chicle. These migrant laborers usually lack the knowledge of the forest and the customary rules. Also, migrant laborers usually lack the skills to harvest in a sustainable manner, often leading to conflicts with indigenous chicleros. 
Producer's participation.

Since the 1970s, Mexico's social movements for reform and democracy have been making the transition from confrontational opposition to the construction of positive policy alternatives. In the process, a new sense of citizenship has emerged, supporting development with a political push for accountable government. Social movements that had previously abstained from electoral politics began to get involved in the often frustrating process of gradually widening small openings in the state at both the local and national levels (Fox, 1992). It was during this time that the Federation became more democratic. In 1978 the president was elected for the first time. Mexican history has long been marked by political conflicts between central and local authorities. In theory, the United States of Mexico is a federation, and state governors have long had considerable autonomy in how they run the affairs of their state. However the president can name candidates and can depose governors. In Mexico, as elsewhere, for most people, most of the time, politics is local. Local in the chicle case means not only the state level (Quintana Roo) but also the municipal level and the ejidal level.

Within the Union chicleros do participate in decisions about production, marketing and distribution. Organizations of producers like the Union are politically important. They not only organize sales and marketing and provide for the materials needed, but also look after social needs like healthcare and pensions. Organizations like the Union and the Federation are not public but are civil society organizations. The World Bank defines such entities as the 'third sector' (Fox, 1997). It is important to recognize the political relevance of these autonomous civil society actors, in this case community-based actors. In the past these organizations have been often been excluded 
from development projects and decision-making. Community forestry in Quintana Roo is often used as an example of a successful inclusion of community-based economic development.

The Federation and the Union are examples of community-based economic and social organizations. Unfortunately, the Federation encountered many problems, and the Union has launched a new effort to develop the chicle industry from inside with participation of the producers. The Union is considered as an important political actor in the relation with other actors like the municipalities, the state of Quintana Roo and the Mexican State. However the chicle industry itself ranks low on the political agenda simply because of the relatively low revenues compared to other sectors like tourism and timber. Conservation of Quintana Roo's forests does have a high political priority. Because conservation of the forest is inherent to the chicle harvesting, it is seen as an important part of sustainable forestry. The conservationist characteristic of the chicle activity is a powerful element in the political strategy of the Union in the participation in the decision making process.

Social capital and trust.

Monopoly is measurable in percentages of sales, concentration of clients and power in the market and so forth, but how do you measure or express trust? Social capital takes many forms. In this case it is specifically interesting to look at the social capital within the group of chicleros and within the institutional structure surrounding them.

From an organization theory perspective, elements of social capital are defined as tacit knowledge, collection of networks, aggregation of reputation and styles. Trust is an important component of social capital. Trust is based on reputation and reputation is 
acquired on the basis of consistent behavior over time, regarding which consistency has value and is the product of human actions. As a society economically develops, its social capital must adapt as well, allowing the interpersonal networks to be partially replaced with the formal institutions of a market-based economy (Stiglitz, 2000). In the case of chicle this indeed has occurred. First, the Federation and, later, the Union are examples of institutions that have emerged from the process of replacement of interpersonal networks with formal institutions. As was earlier described, almost all mentioned components of social capital are present in the chicle activity. Tacit or informal knowledge especially stands out. Chicleros know the forest as nobody else. Through their experience they harvest in a sustainable way without harming the forest and giving cut trees enough time to rest and heal. Also, the social networks and reputation are welldeveloped components of the chicle culture. As was described before, this is most adequately shown by the unwritten customary 'rules' or understandings among chicleros of how the harvest in the forested area is divided among the individuals. This also implies the presence of a fair amount of trust among the chicleros. It can therefore be concluded that chicleros have a form of traditional social capital, but have not made sufficient investments in building more social capital at the level of the Union. .

The lack of trust beyond the community level has been an important factor inhibiting the construction of social capital. Chicleros express great distrust towards the government, intermediaries and even their own representative organizations like the Federation and the Union. One of the most plausible explanations for this is rooted in the history of the chicle economy. First, under the concession system and later under the monopoly of IMPEXNAL, chicleros have always been exploited and never have been 
able to completely benefit from their work, even in the booming times of the chicle industry. However, things have improved substantially since the founding of the Federation and since the liquidation of IMPEXNAL. Direct access to the international market is one of the most important improvements. Still, chicleros have not been able to substantial economic progress. This is no longer due to the older forms of exploitation, but is mainly due to the difficult market situation with low demand and low prices. Reflecting on this history, it is not strange that chicleros look at intermediaries and governmental organizations with distrust. This is best illustrated by the chicleros in The Mayan Zone, as the central region of Quintana Roo is called, essentially the municipio of Felipe Carillo Puerto. Lack of trust in yet another intermediary was the main reason for most chicleros to decide not to join the Union in 1998 and stay within the almost bankrupt Federation instead (Juan Pablo Lemus, personal communication, 2001).

As noted before, trust is based on reputation acquired through consistency of behavior over time. Maybe time has been to short to solve this malfunctioning element of social capital in the institutional structure. Especially in this time when plans are developed for investments in the local production of more value added product, alliances with government and intermediaries are essential. It is therefore important that this element of trust is addressed.

\section{Discussion}

The monopoly of exports, the lack of producer's participation and lack of trust are elements in the institutional structure that currently prevent the more dynamic participation of chicle in emerging markets. 
The controlling position of Mexitrade in the market is a difficult barrier for the Union to face. The current situation of low demand and the powerful position of Mexitrade make it very hard for the Union to compete for clients in the conventional market for chewing gum. Thus, the principal opportunity for the Union lies in the expansion of sales and clients in the organic and fair trade markets.

The Union is an example of community-based development implying a high level of participation of the producers. Although some improvements could be desirable in transparency of the representative organization, it basically is a producers' organization with a high level of participation. However the low involvement of producers in marketing activities impedes the 'bottom up' development of new ideas and the development of more value-added products at the local level. Because of the relatively low economic relevance compared to tourism and timber, it is hard for the chicle sector to participate in a powerful way in the State's politics, though the conservationist characteristic of the chicle activity is a powerful element in the political strategy of the Union.

In current times when alliances between all actors are necessary to bring the development of chicle on a higher level, lack of trust can be a constraint and is important to address. 


\section{SUSTAINABILITY AND ECONOMICS OF CHICLE HARVESTING}

In this chapter the central question is whether the commercial extraction of chicle can be ecologically and economically sustainable. To tackles this question valuation aspects of chicle extraction are reviewed and it is analyzed how the activity contributes to the local economy.

First, the ecologically sustainability of the harvesting practices is discussed. The following paragraphs discuss the valuation of chicle as a natural resource, the contribution to the local economy and the distribution of income of producers.

\section{Ecological sustainability}

To harvest chicle, chicleros make herringbone incisions on the bark of the tree with their sharp machete from the bottom up. The incisions are interconnected, forming $\mathrm{V}$-shaped channels approximately $25 \mathrm{~cm}$ apart and 1.0-2.5 $\mathrm{cm}$ deep; properly tapped trees suffer no damage to the vascular cambium. Chicleros start the incisions at about 30 $\mathrm{cm}$ from the ground, where a small canvas bag is attached. To climb the tree, a chiclero ties the rope around his waist and the tree trunk and usually uses iron spurs on his feet, although a few climb barefoot. Most chicleros make channels all the way around the tree trunk and some also tap the main branches. Healing of tapping incisions and restoration of latex flow is slow. After one day's tapping, the tree typically has to rest about seven years before it can be tapped again. However if incisions are made too deeply (through the vascular cambium), the tree becomes more susceptible to attacks by insects and fungi (Barrera de Jorgenson, 1993). 


\section{Illustration of chicle harvesting (www.junglegum.com)}

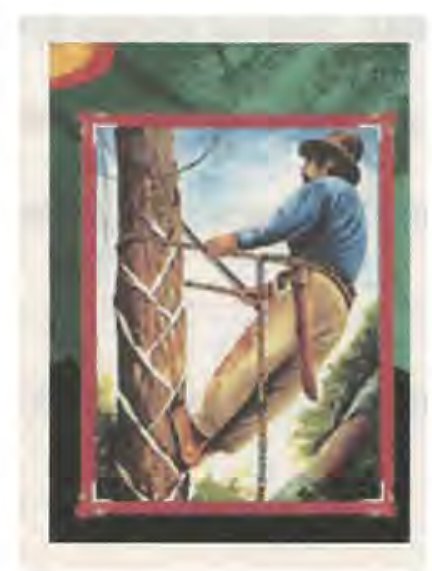

As described before, the chicle harvesting is carried out within the broader community-based forest management. But the community forest management plan was primarily designed for timber production only. Thus, chicle and other non-timber forest products were initially not included in the program. In the past chicle has not been exploited sustainably because the harvest quota were determined by demand. During times of high demand in the early 20th century this has resulted in destructive ways of harvesting causing death of many chicozapote trees and severe decline in production (Snook, 1992). However, this has been changed because of two reasons. First, the demand for chicle dramatically fell in the 1960s due to the substitution of chicle by synthetics and secondly, the government currently requests management studies regarding extraction before issuing authorization for chicle harvesting. In the ejido of Noh Bec this has resulted in the 'Notificación para el aprovechamiento de latex de chicozapote' ('Notification for the extraction of latex of the chicozapote tree'). In this 
communication to the government the extraction is justified and methods and controls for sustainable extraction are worked out.

Unlike timber harvesting, chicle harvesting depends on standing forest and is thus essentially a conservationist activity in itself. Although no trees are cut, still about $10 \%$ of the chicozapote trees die due to bad harvesting techniques.

It is therefore important that harvesting takes place in a sustainable way, according to current guidelines:

- Cutting the tree no further then 1 to $2 \mathrm{~cm}$ in zig-zag form, preventing cutting the vascular cambium;

- The cuts may not cover the whole circumference of the tree, at least $50 \%$ of the tree has to remain untouched;

- Once cut a tree has to remain untouched and rest for 8 years (Noh-Bec2, 1999).

\section{Valuation of chicle as a natural resource.}

In earlier periods, forests had little other value then timber. Thus, forests are frequently undervalued because a wide range of NTFPs are not included in traditional financial and economic analysis of forestry projects. Undervaluation of forests encourages deforestation and causes governments to assign low priority to the forestry sector (Lampietti, 1995). Lampietti developed a framework to include the benefits of NTFP in the valuation of forests. The author defines the value of NTFP in three components; extractive value, non-extractive value and preservation value.

Extractive value is the easiest to measure because it represents goods and, if sold on the market, market value. The value of a good extracted from the forest is equal to its sale price minus the cost of collection multiplied by the quantity collected. I will apply 
this formula to the harvesting of chicle below. Some authors stress the importance of distinguishing between the value of the inventory (the stock of the forest) and the flow (the quantity actually used by people). However, it has also been argued that for most purposes the value of the inventory is a meaningless concept related neither to present nor to sustainable use (Godoy, 1993). In most cases, it is the actual extracted flow that matters on the extractive and community level. It is the value of the stock that may be used in expressing the value of the contribution of total forest production to the regional or world economy. But, if not marketed, the value of the stock remains a meaningless concept at a community level.

Non-extractive values are services such as recreation sites, watershed functions, and carbon sequestration that are provided by the forest. Preservation values include option value, which is the amount an individual is willing to pay to conserve a forest for future use or future generations. It also includes existence value, which is the value an individual places on the knowledge that an asset exists, even though he or she has no intention of ever using it. A complete valuation of the benefits of NTFPs requires estimating the values for all the mentioned components. Estimating the non-extractive values is harder compared to extractive value, because they represent somewhat intangible services, like water flow regulation and recreation, for which prices usually are not available. Preservation values are the hardest to measure, because they are intangibles for which neither quantities nor prices exist, and can only be measured with survey-based questionnaires that describe hypothetical markets (Lampietti, 1995).

The issue of valuation is inseparable from the choices and decisions we have to make about ecological systems. Some argue that valuation of ecosystems is either 
impossible or unwise, that we cannot place a value on such 'intangibles' as human life, environmental aesthetics, or long-term ecological benefits. Another frequent argument is that we should protect ecosystems for purely moral or aesthetic reasons, and we do not need valuations of ecosystems for this purpose. But there are equally compelling moral arguments that may be in direct conflict with the moral argument to protect ecosystems; for example, the moral argument that nobody should go hungry. Moral and economic arguments are certainly not mutually exclusive. Both discussions can and should go on in parallel (Costanza, 1997). In this thesis, the focus will be on the extractive value of chicle as a NTFP and its contribution to the local economy and the conservation of the rainforest of Quintana Roo. It is beyond the scope of this paper to include valuation of the ecosystem (the rainforest) as a whole.

How does chicle exploitation contribute to the economy of communities of Quintana Roo? To determine the value for the local economy of chicle is rather straightforward. It can be derived from the net seasonal income for producer, the number of beneficiaries, price and the volume of production. To determine other values of chicle is a more complicated issue. What differentiates chicle from some of the other NTFPs is its limited use for subsistence purposes. NTFPs that are merely used for subsistence purposes do not have an existing market and therefore the market price is not obvious. Although some chicle is for personal use in the ejidos, most is sold to an well established market and, therefore, has a market price and market value that makes it easier to valuate chicle. The value of chicozapote for chicle is highlighted by the fact that, until recently, it was illegal to cut down the trees in Quintana Roo. In the following section I will look at 
extractive and non-extractive value of chicle production and then look at the importance of chicle for the local economy and the distribution of income.

\section{The Calculation of Extractive Value}

In the following section I use the valuation methodology proposed by Lampietti (1995) to calculate the extractive value of chicle. As noted before Lampietti argues that the extractive value of a Non Timber Forest Product is equal to its sale price minus the cost of collection multiplied by the quantity collected. For chicle this would work out as follows:

Sales price (2001): average US\$ 4.25 per $\mathrm{kg}$ (Aldrete, 2001)

Cost of collection (2001): average US\$2.37 per kg (Aldrete3, 2001)

Quantity collected (2001): average $10 \mathrm{~kg}$ per ha (Noh-Bec2, 1999) Extraction value $(\mathrm{V})=10(4.25-2.37), \mathrm{V}=18$.

It should be noted that prices fluctuate from year to year. The average cost of collection and the average quantity collected remains more or less stable. Data were collected from the ejido of Noh-Bec only and thus the extraction value only applies to this ejido. Although this is a case study of Noh-Bec it is probably valid for other communities as well because of similar production patterns, prices, costs of collection and production quantity.

The extraction value of chicle in the ejido of Noh Bec equals US 18 per hectare. This isolated figure is of limited use without knowledge of the value of other uses of the forest, and the value of alternative uses of the forest, but it is a first step towards this longer process of analysis. Differences per ejido should be taken into account like the 
density of productive trees and diameter of the productive trees in the ejidal forested area.

\section{Non-extractive value}

Does chicle represent other values than the extractive value? The contribution of chicle to the conservation of the environment can be considered as non-extractive value. Conservation of the forests of Quintana Roo historically is closely linked to the harvesting of chicle. Many of the large forested ejidos that exist in central and southern Quintana Roo today were created as chicle extraction reserves. Economically, the revenues of chicle were competitive with those of timber extraction and therefore the activities could co-exist and the forests were not entirely subject to logging. During the high times of chicle in early years of the 20th century the forests of Quintana Roo and Campeche could be considered 'extractive reserves' decades before the concept existed in Brazil (Galetti, 2001). However the situation now is completely different and, as noted before if not over-harvested, extraction of chicle has, when carried out carefully, not harmful to the trees, little ecological impact. It is important that the cutting cycle (ciclo de pica) of 7 to 8 years is observed (Ramírez Aguilar, 1992). Besides that the chicozapote tree is an important source food source for wildlife. Because trees are not removed the extraction of chicle has no major impact on the wildlife nor on other parts of the ecosystem except for the impact caused by the chicleros living in and from the forest resources while harvesting (Noh-Bec2, 1999). But also this has changed over time because of improved means of transportation. Nowadays most chicleros travel back and forward from the forest to the village each day and no longer remain in the forest during the harvesting. 
To fully understand the contribution of chicle to the conservation of biodiversity it should be taken into account that chicle exploitation is part of the forest and closely linked to the forest management plan as described in the chapter on the Institutional Structure. There it is described how important the chicle harvesting is as part of the diversified extraction of goods from the forest. Although the non-extractive value, the contribution to conservation, is more difficult to calculate as the extractive value of chicle, the foregoing suggests that chicle contributes to the value of the ecosystem in both ways.

Importance of chicle extraction for the local economy.

Though the harvesting of chicle is not as lucrative as it was during the 1920s and 1930 s, this industry still plays a significant role in the economy of Quintana Roo's rural community. Annual average production in the state of Quintana Roo is about 400 tons, with a value of about US\$1.5 million (Kiernan, 1999).There are about 5,000 chicleros (about $5 \%$ of the rural population) most of whom are Maya Indians(Barrera de Jorgenson, 1993). Currently less then half of the producers are actively extracting chicle because of low demand.

From the market standpoint, the present and also the future of the chicle is insecure. The statistics of demand have been capricious since the synthetic substitution for chicle was invented after WW II. In figure 9 the production from recent years is presented. 
9. Chicle production of cooperatives of the Union de productores de chicle natural, in $1,000 \mathrm{~kg}$ (Aldrete2, 2001).

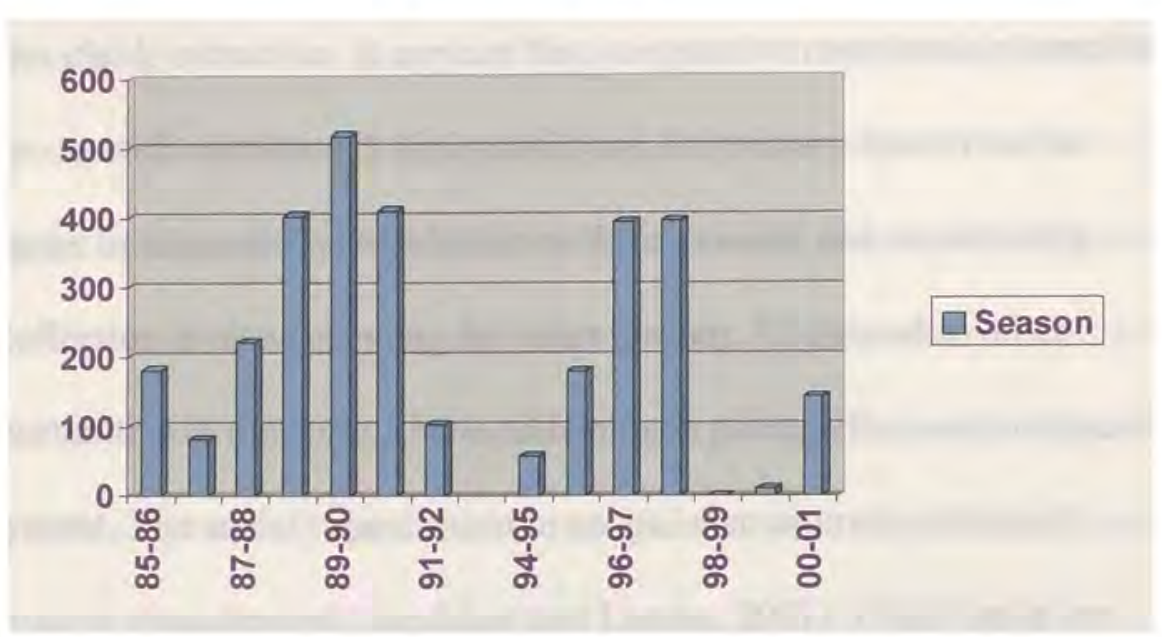

As is shown by figure 9 the production has been highly variable and is therefore unpredictable. There have been some years with almost no production at all. There are two main reasons that explain this variability. One is the institutional situation in the season 1993-1994 when the Federation was in a state of financial chaos. The other nonproductive period is explained by the market because the production of the previous season was not sold during the same season. There was still sufficient product in storage to supply for the following season so no new product was harvested.

For years chicle was one of the most important motors of the regional economy, however, as mentioned earlier this has been changing over the last fifteen years. Since 1985 community based logging, promoted by a government program known as the in the in the foregoing chapter discussed Forest Pilot Plan (Galetti, 1998) complemented the chicle activity and substituted for the decline of chicle markets. However, chicle still provides for a substantial part of the income in many ejidos. Barrera de Jorgeson found that for historical and economic reasons chicle continued to be a vital source of income 
for most residents in the ejido (X-Hazil y Anexos,) where she conducted her research. Except for milpa agriculture, no other economic activity in the ejido employs as many individuals as does chicle extraction. It appears that cooperative membership benefits such as health care as well as relatively high profits are the primary incentives for ejidatarios to engage in this activity. In addition to the economic and membership benefits, chicle collection is also appealing for other reasons. Compared to other employment opportunities in the ejido, chicle collection is perhaps the most independent source of employment. The social organization in an ejidal structure is a form of common pool resource management (Sarukhán and Larson, 2001). Ejidal lands are exploited by the community, no individual profits are made but the income and profits are divided among the members of the ejido. In Quintana Roo most of the ejidos are forestry communities. The general assembly of the ejido appoints individuals to serve as extraction team chiefs, sawmill administrators, etc. Waged employment in the communal forest takes place under supervision of the team chiefs and assembly. Marketing and finances are handled by the commissioner but under strong influence of the assembly (Taylor, 2000). Nowadays the forest is mainly exploited for timber but also for chicle and other NTFPs like palm leaves, honey and orchids. As described in foregoing chapter on institutions, the difference between chicle and other natural resources like timber is that timber is considered as a communal activity on the common property of the ejido. The access to the resource is determined by that communal use like, for example, the communal yearly harvest quota. Whereas chicle is an individual activity, access to the resource is more free compared to timber. Like timber, the harvesting takes place on the common property of the ejido and is therefor subject to the general ejidal rules. But 
because of the individual nature of the activity it not subject to communal appropriation as is the case with timber.

The individuality is not without conflict. Some ejidatarios argue that the chicleros should contribute more financially to the common property because they make use of the common property facilities such as the opening of trails, the maintenance of roads and certification of the forest without contributing proportionally of their incomes. According to those critics the derecho de monte paid by chicleros for the use of the common' property forest is not compensating for all those common facilities. On the other hand it is recognized by the same critics that the current precarious situation of the chicleros does not justify for increasing their contribution to the common resources.

The chicle profit is not divided among the ejidatarios but is individual income for the chiclero. It is totally up to the skills, labor time and effort of the individual chiclero how many kilograms are harvested and how much he earns. This is a fundamental difference with those working in timber. Timber profits are distributed among all ejidatarios - loggers and non-loggers. Since everyone gets an equal portion of the profits, the general assembly of the ejido tends to keep the logger's wages low (Barrera de Jorgenson, 1993). In the table below data is presented of the role of chicle in contributing to household incomes from forest-based activities for one community in Quintana Roo. 
10. Mean cash income earned from chicle extraction (annual US\$) by 15 chicleros during 1989-1990.

\begin{tabular}{lcccccc}
\hline Chiclero & Chicle & Logging & Railroad Tie & Honey & Other & Total US\$ \\
production category & & & & & (a) & \\
\hline Low & 381 & 41 & 50 & 12 & 98 & 571 \\
Medium & 485 & 0 & 60 & 18 & 116 & 687 \\
High & 1092 & 473 (b) & 19 & 0 & 0 & 1,584 \\
\hline
\end{tabular}

(a) Employed by the ejido. In 1989 the ejidos daily salary was US $\$ 4$ a day, (b) Chiclero number 15 owned a chain saw. Note: Total income does not include US\$200 each from timber profits distributed among ejidatarios(Barrera de Jorgenson, 1993).

Although my research did not systematically collect data on forest-based income, interviews in Noh Bec suggest similar patterns to those identified in the figures presented in figure 10. As in Barrera's findings chicleros can still earn a higher income compared to other economic activities in the ejido. Official financial data from ejido Noh Bec resulted in the conclusion that an average chiclero can obtain almost twice as much monthly income compared to most wage-workers in the ejido during the 6 months of the rainy season (Noh-Bec, 2001). This makes the chicle activity an attractive source of seasonal income for chicleros.

A special advantage of the harvest season of chicle is that it is complementary with the timber season. Usually the work in timber slows down in the fall just when the rainy season and thus the chicle season is about to start. Although seasonal, for those with the adequate skills and experience it turns out to be economically attractive to 
engage in chicle during the rainy season even with current low demand as is shown in this paragraph.

It must be noted however that because of limited demand only a few ejidos are currently actively engaged in chicle extraction resulting in impoverishment of those who were involved before and did not find a substitute for income during the rainy season (Chicleros, 2001).

In summary, the income that may be derived from chicle at a local level is attractive compared to other employment opportunities in the ejido. It provides for income in normally slow times for timber (the rainy season) and has the advantage of being an individual income not to be shared with other ejidatarios. The main threat to these positive elements for communities is the low demand and the low prices in the current chicle market. In addition to the monetary returns, chicleros receive social security in the form of health care benefits and life insurance. The Union de productores de chicle natural (to be discussed further below, collects the contribution of chicleros and sets it aside in a separate health care and insurance funds (Fondo Chiclero). In practice the payment of health care and life insurance leads to conflicts between chicleros and Union and is not working in a satisfactory way for all involved parties.

\section{Estimated Potential production capacity in Quintana Roo}

Studies have calculated the potential production capacity of Quintana Roo (Ramírez Aguilar, 1992). It is important to note that Ramírez based his calculation of potential production capacity upon sustainable production. A harvest cycle of seven to eight years is considered to be appropriate in order to guarantee a production that does not negatively affect the health of the harvested trees. Another important sustainability 
criteria is the minimum diameter of the harvested tree. According to Ramirez, trees with a diameter smaller then 25 centimeters should not be harvested.

Potential production capacity is calculated using the following formula:

$$
\mathbf{P}=\underline{\mathbf{A} \times \mathbf{R}}
$$

\section{CP}

$\mathbf{P}=$ Potential Annual Production

$\mathbf{A}=$ Permanent Forested Area

$\mathbf{R}=$ Return/yield per $\mathrm{Ha}$

$\mathbf{C P}=$ Harvest cycle

In figure 11 it is shown how this results in the annual potential production capacity for Quintana Roo.

11. Annual potential production capacity for Quintana Roo

Technical overview of chicle production in Quintana Roo (Natural, 2000)

Total Productive forested area Quintana Roo

Average of productive trees

Average of production per tree

Minimum diameter (at breast height)

Harvest cycle
500,000 hectares

25 trees per hectare

$0.600 \mathrm{~kg}$ per tree

25 centimeter

5 to 8 years 


\section{$\underline{500,000 \times 15}$}

8

Thus, the total estimated production capacity is around 900,000 kilograms per

year. This is far above the current average annual production of 220,934 kilograms in the period of 1985 until 2001, and shows a significant underutilization of the chicle resource in the state.

In Figure 12, below, the recent trends in chicle sales in the state of Quintana Roo are presented.

12. Sales chicle in $1,000 \mathrm{~kg}$ of the cooperatives of the Union de productores de chicle natural (Aldrete2, 2001).

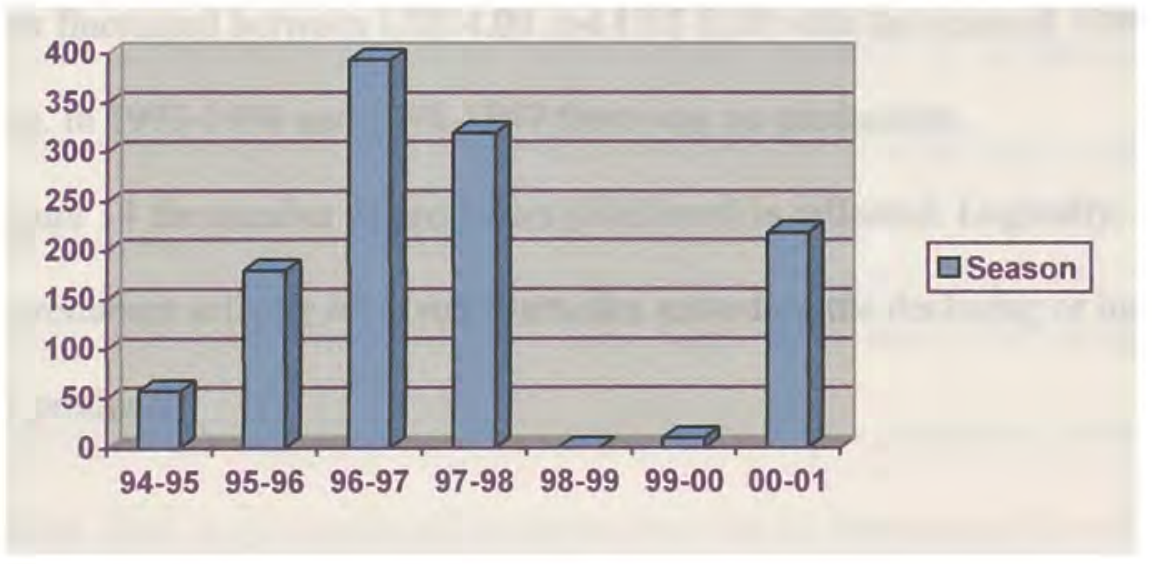

From 1994 to 1997 the sales figures showed a positive trend. In 1997 however sales started to slow down and totally collapsed in 1998. It is not completely known why sales were so depressed during these years. The explanation of representatives of the 
Union is that there was a general declining trend in chicle-demand and there was still sufficient chicle in storage at the contractors warehouses during 98 and 99 so there was hardly need to buy any new chicle.

13. Prices of chicle per $\mathrm{kg}$ in US dollars(Aldrete2, 2001).

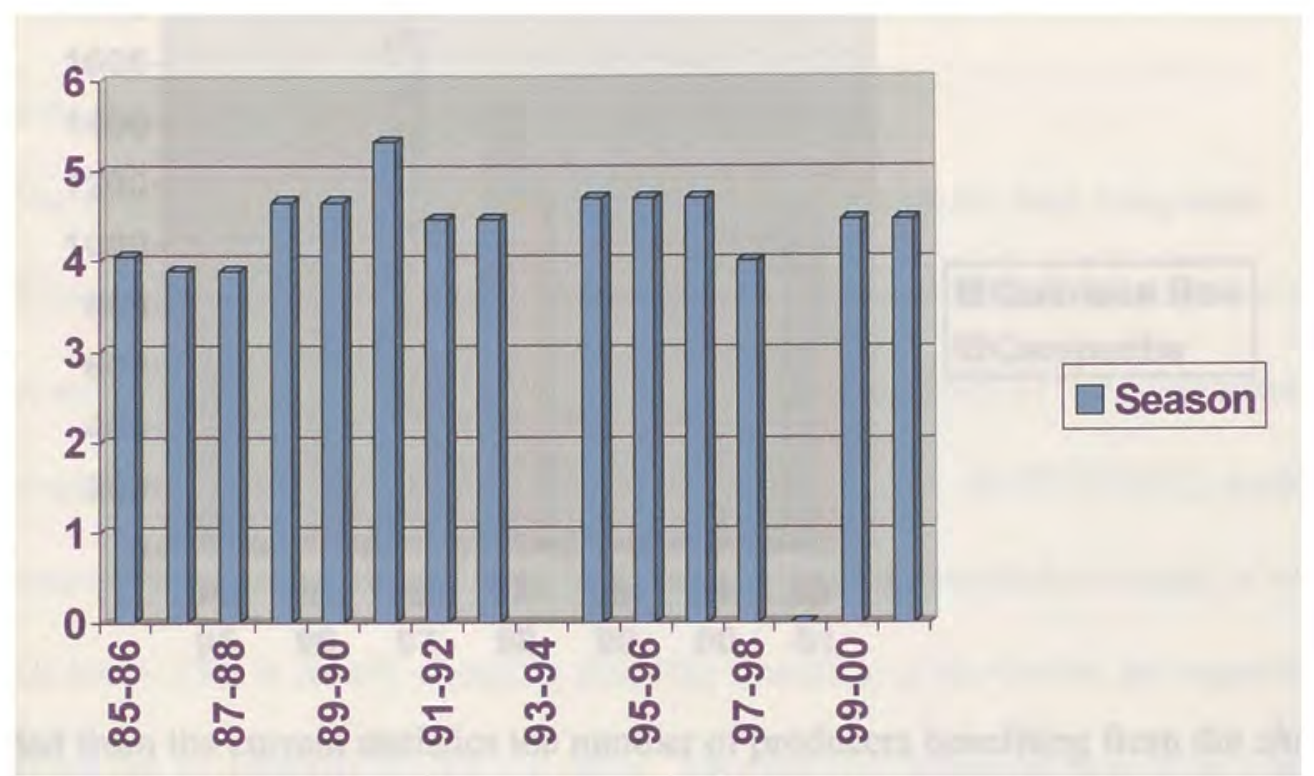

Prices fluctuated between US\$ 4.00 and US\$ 5.00 with the years of 1990-1991 as an exception. In 1993-1994 and 1998-1999 there was no production.

In figure 14 the number of producers (chicleros) is reflected. Logically, the number of producers actively involved fluctuates according the declining or increasing demand for product. 
14. Number of Producers (Aldrete2, 2001).

The number of producers logically tracks production and sales. As can be

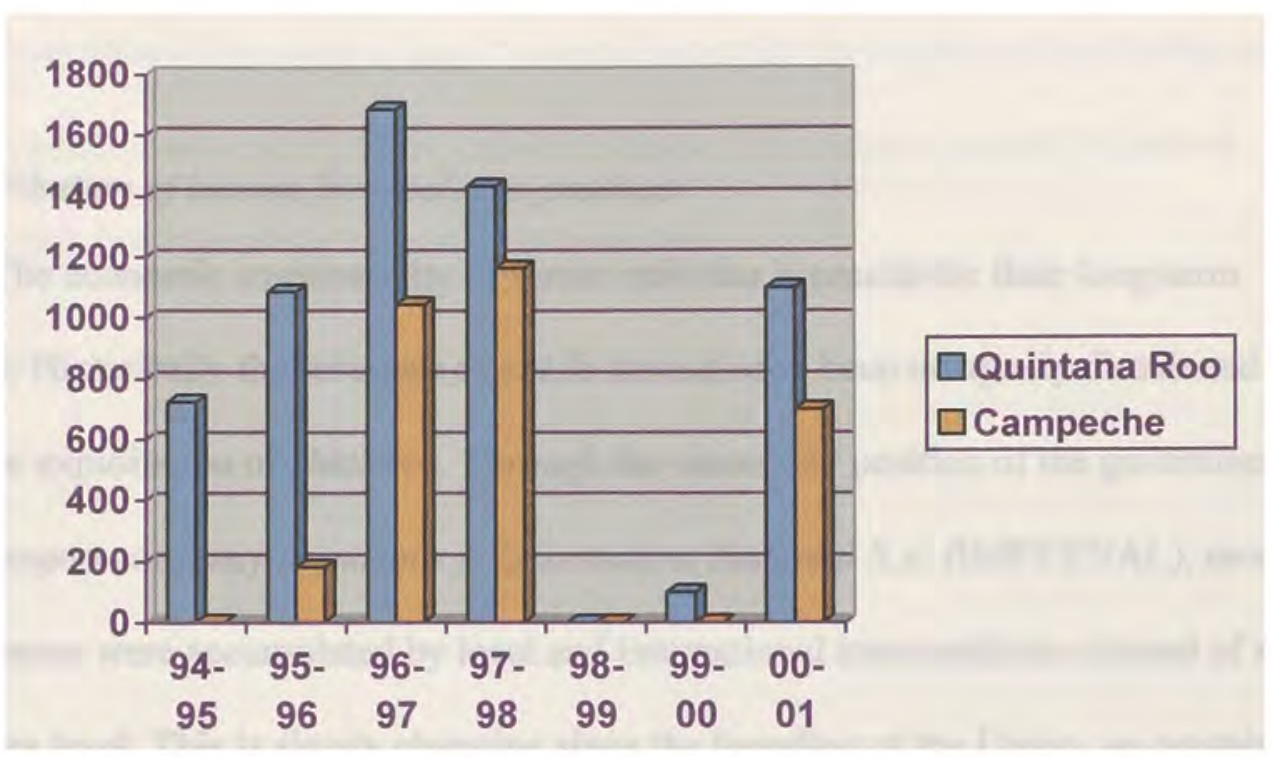

concluded from the current statistics the number of producers benefiting from the chicle activity is small in absolute terms. These statistics only represent the production and benefits of those producers who are affiliated to the Union that constitutes nearly all producers in the state of Quintana Roo.

Nowadays the economic activity of chicle might not be one of the strongest and might benefit relatively a small amount of people in the region compared to timber and migrating labor. Still, it is considered important because for those people involved it provides for a substantial income. Survival and increase of the industry's benefits is crucial for many families.

As currently produced, chicle has a very low value added. It is a semi-processed raw material that commands a very low and unstable price in the market. As a response 
to this problem, there have been proposals for the development of a chewing gum or gum-base factory in Quintana Roo to determine the future development of the economic activity for the region. If this project comes to fruition, it will include more people in the production process and add more value to the product for the local economy of Quintana Roo.

The distribution of income from sales to producer

The economic sustainability of forest activities is crucial for their long-term survival. Historically the revenues of chicle have always been unequally distributed due to severe exploitation of chicleros. Through the monopoly position of the government owned export company Impulsora y Exportadora Nacional S.A. (IMPEXNAL), most of the revenues were accumulated by local and international intermediaries instead of at a producers level. This is slowly changing since the founding of the Union, an organization representing the cooperatives of the chicleros. The growing independence of the Unions' biggest client, Mexitrade, and the effort of the Union to diversify its clients are important steps in gaining more control on the pricing of the product. But until now it can be concluded that there is a huge gap between the earnings of the producers and the revenues generated outside the local economy.

Mexico's chicle producers currently receive 3 US cents per kg according to interviewed chicleros in the ejido of Noh-Bec. On the international market one $\mathrm{kg}$ is sold for an average price of US $\$ 4,50$. The end product (natural chewing gum) is sold at a price of about US\$2.00 per package ( 21 grams). Usually the gum contains no more then 1 or 2 grams of other ingredients like sugar or flavorings. This means that the consumer price of US $\$ 2.00$ for about 20 grams of natural gum would result in a price per $\mathrm{kg}$ of 
about US\$100. Obviously, substantial costs are incurred in production, transport, packaging and marketing which should be taken into account. Because there is no accurate information about this at the time of writing, these could not be included in the equation. However, although the information is incomplete it can be said that there is a tremendous price differential related to control over the processing and marketing of chewing gum, mostly taking place outside Mexico. This element should be further investigated, however, based on more precise data. 


\section{MARKET AND MARKETING}

In this chapter, I first will explain different types of certification currently applicable to natural chewing gum Secondly, I will concentrate on the commodity chain and control over different parts of that chain. In the third section I will discuss the dynamics and characteristics of emerging green or certified markets and marketing messages, with some reference to the markets for conventional chewing gum.

\section{Certification}

The main goal of fair-trade certification is that a higher amount of the revenues of a product flow into the pockets of the producers. Fair-trade certification tries to assure a more equal distribution of income within the chain of retailers, manufacturers and producers. The payment of a 'fair price' in the fair-trade market is determined by labor time and costs and provides a real compensation for producers. Although these markets are still small and new, they form a great opportunity to increase independence of intermediaries and to provide for a substantial increase of revenues for producers leading to a more equal distribution of revenues. Whether certification really obtains these goals should be evaluated in each individual case.

Certification under the Forest Stewardship Council (FSC) is aimed at conservation of forest and sustainable exploitation of forests. In the case of chicle the certification for ecological sustainable production under the Forest Stewardship Council (FSC) procedures is relatively easy to obtain when timber-harvesting operations are already certified under FSC as is the case in the ejido of Noh-Bec. Chicle is part of the general forestry activities and can relatively easily be included in the sustainable forestry 
evaluation. Certification for organic production is to certify that the product does not contain synthetic components but pure natural ingredients. All types of certification are used in the marketing messages to consumers.

Natural chewing gum is mostly marketed as an organic/green product not containing synthetic components but pure natural ingredients. Conservation of the rainforest and contribution to the fair compensation of rural people are the other marketing pillars of the natural gum product. Chicle companies involved in the certified fair trade business pay the highest price per kilogram of chicle compared to other buyers that do not have such a fair-trade certification. Fair-trade and organic chewing gum is sold to the high-income ecological conscious consumers in the niche markets for organic (green) and fair trade products willing to pay higher prices then the regular consumer. It should be noted that to obtain any type of certification substantial costs have to be made. Within the ejido of Noh-Bec discussions are ongoing that chicleros should contribute part of their income to the costs of the forestry certification process, because they benefit without contributing. How the individual chicleros exactly benefit from certification is not clear. Sales certainly have not skyrocketed since certification. A fact is that for fair-trade certified chicle the highest price is paid to producers, but whether this market premium of the fair trade markets is sufficient for the survival of the chicle activity is not clear.

The experience in Mexico with the small-holder organic coffee producers showed that although certification is essential it is certainly no panacea. The success of Mexico's small-holder organic coffee producers seemed to be more a result from organizational innovations, development of sustainable institutions at the community, regional and 
national level. Through these institutional improvements communities improved their negotiability on a national level and in the international markets (Bray, 2001). For positioning themselves in the international markets this is of the highest importance. Another important limitation to certification is that few consumers will buy a product or pay a premium only because of its environmental or social values, it must also be of high-quality (Bray, 2001).

\section{Commodity Chain and Control}

The control of producers and other organizations over the commodity chain of chicle is described to give insight in to what extend control over parts of the distribution chain impedes the chicle activity to evolve in the right direction of providing more benefits for producers. Where along the chicle commodity chain can producers and their organizations gain control from private intermediaries? A commodity chain approach (Porter, 2000) offers valuable insights into not only the constraints but also the opportunities for producers and their cooperatives. How does the restructuring of state, national and sub-national institutions affect control over different nodes of a commodity chain? The prospects of producers are related to their ability to scale up the commodity chain and to capitalize their producer cooperatives and unions. Focusing on who controls which stages of a commodity chain sheds light on who is winning and who is losing in the marketplace (Porter, 2000).

Chicle passes through a commodity chain from the time the latex is harvested from the tree and to the time the consumer chews on the piece of gum. While a few big factories control much of the final processing of chicle into gumbase, numerous other 
candy companies control the flavoring, packaging and marketing of chewing gum as the end product.

Only three companies control the market for the natural chewing gum market: Speakeasy, GleeGum and JungleGum. Speakeasy is the natural chewing gum brand of Mexitrade based in Mexico City. JungleGum is a small natural chewing gum retailer based in Gainesville, Florida USA. GleeGum is a natural chewing gum brand that is merely marketed through the Internet. It is not clear what retail or production company is involved in this brand.

Control Production, Marketing and Distribution.

Unlike Mexico's small-holders in organic coffee, chicleros did not steadily gain control over various steps in the processing stage. At the producers level almost nothing has changed, still the same marquetas are delivered as the local end product as was done 100 years ago. Looking only at the price difference between raw material and end product, it is obvious that it would be more profitable for producers to gain control over more aspects of the commodity chain. The first step in vertical integration would be the local production of gumbase that can be sold to the companies making the final end product of chewing gum. At this point it is not known what exact kind of investments would be involved in the establishment of a gumbase facility. Also, it is not known at this moment how much of the value added for chicle occurs at the process of making gumbase.

In order to be able to produce a more value added product, some sort of credit has to be provided to the producers (the Union) to facilitate making these investments. Due 
to their economic situation, no investments of producers or Union can be expected on a short term.

In the 'conventional' chewing gum market, only Japanese producers still use natural gum in their production process of gumbase. All the other companies only use synthetics in producing chewing gum. This was the main cause for the dramatic fall in demand for chicle.

As noted before the natural gum market is controlled by three companies: JungleGum, Speakeasy (Mexitrade) and GleeGum. The same companies are responsible for the distribution and marketing of natural chewing gum.

Speakeasy is made by Mexitrade in Mexico City. Curiously enough, they are the ones least benefiting the chicleros because they pay the lowest price. In 2001 JungleGum paid US\$ 5.25 per $\mathrm{kg}$ whereas buyers like Mexitrade paid US\$3.50 per $\mathrm{kg}$ and Mitsuba US $\$ 4.70$ per $\mathrm{kg}$ (Aldrete, 2001). In the case of JungleGum a 'fairtrade' price is paid in order to guarantee chicleros a proper payment for their work. The participation of producers in marketing is very low. This can be illustrated by the fact that some chicleros still think that conventional chewing gum (the big American producers like Wrigley) use natural gum in their production process. Although producers are familiar with chewing gum, they don't understand that some of the product is going into new "green" markets, and have never seen packages of natural chewing gums currently made of their chicle. This lack of understanding of the current market leads to distrust between producers and intermediaries because it is not really understood why no better revenues can be obtained. Although these small cooperatives of chicleros have the potential of being able to quickly respond to market signals because of their size and structure, if they do not 
have contact with the market, to what do they respond? It is a big challenge for the Union to try to ally with the government in an effort to involve in value-added processing and in gaining more control in the production, distribution and marketing chain.

Referring to figure 6 in chapter 3 'Concentration of clients in percentage of total sales', Mexitrade buys about $50 \%$ of the total production of the Union. Part of the chicle is used to produce their brand of natural chewing gum 'Speakeasy'. But Mexitrade sells most of it as an intermediary to international clients; some of them are intermediaries themselves. Mexitrade is a very powerful player in the Mexican chicle because of its strong relations with the international clients. Mexitrade uses its market position to keep prices down and sometimes does not pay at all because of accusations of a poor quality product delivered by the producers.

Every season the quantity and the prices are negotiated. Because of the current market conditions, potential supply in the region is much higher than the demand, bringing about great insecurity for the producers every year. The Union has been able to establish some direct market contacts that are willing to pay better prices, benefiting directly to the producers it represents.

The chicle product and its consumers; certified chicle and non-certified chicle.

Fortunately for the chicle industry, not all conventional chewing gum companies switched to synthetic substitutes. A few companies, primarily in Japan, Italy and Mexico have kept the industry alive (Barrera de Jorgenson, 1993). Japanese companies continue using chicle as raw material together with synthetic ingredients. The natural chicle components contribute to the elasticity of the gum complying with Japanese consumer demand (Katsube, personal comment). 
The emerging markets for organic and fair trade products is a relatively new opportunity for the survival or revival of the chicle industry. Consumers of organic or green products avoid products made of synthetic material if a natural product is available. Chewing gum based on chicle fits this consumer demand. Another motivation to consume organic/green products is the contribution of the product to the conservation of biodiversity. The extraction of chicle, if not overexploited, contributes to the conservation of the ecosystem of the chicozapote tree. In fact the chicozapote tree is so dominant in these forests they have been called manilkara forests.

Consumers of fair trade products have yet another motivation for buying these products. Their motivation is to make sure that small holders, farmers and producers obtain the maximum of benefits and a price that compensates them for real production costs and labor and therefore is defined as a 'fair price' or 'fair trade'. In the current system of world capitalism it is hard for small holders, farmers and producers to compete with mass-producing multinationals and to negotiate with intermediaries for a reasonable income. Chicle gum complies with these specific consumer demands; the revenues are intended to benefit chicleros in Quintana Roo.

These niche markets give chicle gum a competitive advantage compared to the mass consumed synthetic gums.

Due to the mass production and consumption of synthetic gums, it is by no means a reality for chicle gum to compete on these conventional consumer markets. The continued demand for chicle by Japanese producers and the growing demand for chicle gum in the emerging markets for organic and fair trade products give an opportunity for growing demand for chicle in the future after the crisis in demand in the $1980 \mathrm{~s}$. 
The unique selling points of chewing gum and natural chicle

The main characteristics that are promoted in sales of chewing gum for the traditional chewing gum markets are freshness, flavor and cleanness. For products in these markets it is very important that it complies with the expectations of the consumers. The marketing of chewing gum for the conventional chewing gum market merely stresses the benefits of gum of sweetening the breath and refreshing the mouth and throat because of the flavor. Marketers stress the function of chewing gum in healthy teeth because of the stimulation of saliva that helps to neutralize acids from foods that may cause tooth decay. Another important selling point of chewing gum is that chewing of gum eases stress and improves concentration.

For natural chicle many of these selling points are the same. It also aims to provide for a fresh breath, clean teeth with a relaxation effect of the chewing in itself. Natural chewing gum, however, has two extra unique selling points, namely health and environmental protection. Consumers that are very conscious of their diet for health reasons might not use conventional chewing gum because of all the artificial ingredients and flavorings it contains. These consumers might consider chewing gum that does not contain any artificial ingredients and is $100 \%$ natural. Further, the environmentally conscious consumers may be appealed by the fact that the production of natural chewing gum contributes to sustainable forestry in the rainforests of Mesoamerica.

These two unique selling points, health and environment, of natural chewing gum make it suitable for access to the emerging markets for green, organic and fair-trade products. For chicle production the exploration of these emerging market is critical, because the amount of chicle used in the production process for the conventional 
chewing gum market is uncertain and declining. The emerging markets of the organic food products and fair-trade products might give access to new consumers and consequently a growth in sales. Another opportunity for chicle producers is that the fairtrade market for certified products offer a higher price (a 'fair price') per kilogram as is described in the foregoing section.

Especially because the current situation and current demand is simply not good enough for a healthy productive industry, the need to access emerging markets is high. Natural chewing gum can be classified as an organic food product because of its edible quality, its natural ingredients and its environmentally sustainable production. Only natural gum that obtains fair-trade certification and contributes economical sustainably to the local production communities can be qualified as such. Later in this section, I will review the certification status and marketing strategies of the three alternative brands of natural chewing gum on the US market.

\section{Characteristics of consumers of organic food products}

In this section, I will review the potential of natural chewing gum in the emerging markets for organic food products in the Netherlands and the USA. The purpose of this characterization is to gain insight about these potential consumer groups and to investigate which marketing messages may be useful in allowing natural chewing gum to penetrate these emerging markets.

Consumers of organic food products in Europe

In Europe and more specifically in the Netherlands, the demand for organic food products is constantly increasing. At the moment one out of every five Dutch consumers 
has a preference for organic products (de Wit, 2001), with about five million people preferring natural food products over products that contain artificial ingredients.

The Dutch company Motivaction recently launched a research model called 'Socioconsult' on the Dutch market. This research model categorizes consumers and consumer groups differently from conventional market research models. Consumers and consumer groups usually are categorized according to family type, income and age. However the Socioconsult's model differentiates seven types of "social environments" and so called 'undercurrents'. A social environment consists of a group of people with comparable mores and values and the 'undercurrents' are developments of changing needs and values. Consumers are characterized according to lifestyles and values rather then by income, family or age. Motivaction believes that this way of looking at consumers explains much better their purchasing behavior.

Figure 15 shows the seven main groups in percentages and absolute value of population. 
15. Social structure Dutch society.


According to this scheme, the three main groups of consumers that buy organic food products are the 'Post-materialists', the 'Cosmopolitans' and the 'Traditional Bourgeoisie'. Post-materialists are a relatively small group within the Dutch population, about $9 \%$ of the population. This group is characterized by an environmentally conscious lifestyle, political activism, and a search for harmony and solidarity. Income, education and age is highly variable within this consumer group. The Cosmopolitan group is a little bigger, $11 \%$ of the population, and consumers belonging to this group are career oriented and concerned about society and community at the same time. Their lifestyles are characterized by variety and activity and usually are people with a high 
income and high education. The Traditional Bourgeoisie is the largest of the three groups of potential organic food products consumers, with twenty-two percent of the Dutch population. belonging to this group. Consumers categorized in this group are characterized as being conservative, solidary and value family life. They are disciplined, are socially involved, have a Calvinistic lifestyle, and are usually people over forty years old with a low or average education.

Each group has a different motivation to buy organic food products. The majority of the Cosmopolitans are interested in organic food products for health reasons. These consumers can be characterized as adventurous and willing to try out new products. they are generally willing to pay a higher price for organic food products because the majority of these groups have discretionary income they are prepared to invest in this way.. Consumers belonging to the Traditional Bourgeoisie have an average interest in organic food products, but may be an interesting target group because of their extreme valuation of healthy food products. This group may be more price-sensitive however, and not have the willingness to pay higher prices for products, because of concerns about balancing price and quality.

The Post-materialists are the only consumers that explicitly consider broader environment concerns in their purchasing decisions of organic food products. Like the consumers belonging to the other two groups, they are concerned with their health but also value the environmental sustainability of the production of the products they buy (de Wit, 2001). Thus, it can be concluded that the Post-materialists are the most important target group for organic food products like natural chewing gum because their consumption decisions are motivated by environmental concerns. They prefer products 
that contribute to a sustainable environment and are healthy at the same time. Secondly, the Cosmopolitans may be an interesting target group for natural chewing gum because they prefer to consume natural products to products that contain artificial ingredients. The consumers of the Traditional Bourgeoisie are a potentially interesting target group because their concern for health. Their less adventurous consumption pattern might be a barrier to try out new things like natural chewing gum.

It can be concluded that only one consumer group (Post-materialists) consider the environmental sustainability of the food products they buy in their purchasing behavior. Health seems to be the more appealing quality of organic food products like natural chewing gum for most of the potential consumers. This is important to take into account in marketing messages about natural chewing gum.

\section{Consumers of organic food products in the USA}

In the USA consumers of organic food products have been classified by the Natural Marketing Institute in 'Understanding the Lifestyles of Health and Sustainability (LOHAS) Market: Identifying the LOHAS Consumer and Business and Marketing Opportunities' (French, 2002). Similar to the Dutch Socioconsult, consumers have been segmented according to their attitudes and behaviors across a wide range of LOHAS criteria. This new, general population consumer segmentation shows that the LOHAS consumer represents an impressive 30 percent of all U.S. households or 63 million adults. Two defining characteristics that set the LOHAS consumer apart from the general population include willingness to pay up to $20 \%$ more for LOHAS-related products and a willingness to teach family and friends about the benefits of these products - both 
extremely important behaviors for facilitating the identification of future trends (Lampe, 2002).

Furthermore, LOHAS consumers are not simply environmentalists; what drives LOHAS consumers is health - that of their families and the planet, and the future of society. Their dominant concerns are for social justice, conservation of natural resources, personal development and the wellness of body, mind, spirit and planet, and these values seem certain to play an increasing role in the shifting consumer markets of the global economies in the world today. Some of the drivers of LOHAS consumers are very interesting for the marketing of natural chewing gum. Consumers belonging to the LOHAS group choose environmentally friendly products and make purchase decisions based on the effect on the world. Besides that, they favor sustainable agriculture practices and are willing to pay 20 percent more for sustainably made products (French, 2002).

Beyond the LOHAS consumers there is a group called 'Nomadics' that are consumers who are leaning towards the group of LOHAS. While these consumers are yet to be labeled as a pure LOHAS consumer group, they are moving towards the LOHAS group because they increasingly make buying decisions based upon values of health and sustainability. This group is the largest single segment of consumers (38\%) and comprises about 79 million U.S. adults, a further indication of an emerging consumer market that represents significant opportunities for companies like that active in natural chewing gum. Combined, the LOHAS consumer group and the LOHAS-migrating Nomadics represent a market of more than 90 million adults in the USA - a complex structure of consumers that defies traditional demographic categorization (Lampe, 2002). 
This represents a significant opportunity for the marketing of natural chewing gum using its unique selling points of health and environmental protection.

Chewing gum, however, also has a serious limitation in being able to penetrate these markets. Chewing gum itself is not a product that is particularly associated with a healthy lifestyle or one that contributes to it. That this limitation is serious was confirmed by interviews carried out at an organic food market in New York City. Ten organic product consumers shopping at an organic market, were asked if they consumed chewing gum, the reasons why (not) and if they would consider buying organic chewing gum. Most of the interviewees buy organic products for health reasons. Six of the ten interviewees said they chewed gum, while four said they did not. Those who chewed gum said they would stop eating gum if they could because they considered it as a bad and unhealthy habit because of all the sugar and artificial additives it contains. The 'chewers' said they would definitely buy organic chewing gum for health reasons and ethical reasons if it would not be significantly more expensive then conventional chewing gum. Not surprisingly, of those who did not chew gum, only two people said they would try it, but they did not consider it likely that they would buy organic gum on a regular basis.

Obviously, the results of these interviews are statistically not significant because only ten consumers were interviewed and conclusions can not be based upon these observations. The results are interesting enough to include here because they indicate that, just as within other consumer groups, a significant part of organic products consumers do not chew gum and will not change that habit even though there would be an organic alternative. On the other hand, the 'chewers' under the organic product 
consumers appear to be very perceptive to an organic alternative so they can change their 'bad habit' into one that fits within their organic life-style.

In the following section, I will review the sorts of consumer choices, which are being offered in the certification movement, and look at how the marketing strategies of current natural chewing gums are using or abusing these certification seals. All of these certification seals depend upon the concept of "third party" certification, that is an independent body with no direct stake in the production or consumption of the product that makes an independent inspection as to whether or not certain certification criteria are being met.

Fairtrade

Fair trade certification seeks to minimize the number of middlemen by doing business directly with the producers, organizations of craftsmen and farmers, or companies with good social policies. Products are purchased at a "fair" price which would be negotiated in each individual case, but is above prevailing market prices for the production in questions, and only if the conditions of production are considered to be non-exploitative by independent inspection.

Producers are paid in advance, in order, for example, to bridge the period between sowing and harvesting. Producers can also receive technical assistance, when, for example, they wish to improve their products and their production methods. Fair Trade stimulates good working conditions and environmental awareness. There are special concerns that fair trade products do not use child labor and that women have the opportunity to participate in production and profits. Fair Trade Assistance provides for advice, training and support of producers in developing products. Also, commercial 
advice or assistance in the field of organizational expertise or the improvement of production methods is provided.

The principles of fair trade were introduced by the Fair Trade Organization in 1967, and for many years it was confined to small niche markets in Europe. While still strongest in Europe it is slowly spreading into other parts of the world. However, most of the fair trade organizations are still located in Europe. In different European countries a total of fourteen fair trade organizations exist. In the rest of the world only one fair trade organization is located in the USA, one in Canada and one in Japan. But the longer tradition of fair trade programs in Europe is shown not only by the number of organizations but also by the product assortment. Thus far, for example, the Oakland, CA based US fair trade organization Transfair only works in the field of fair trade coffee and tea. By contrast, the fair trade organization in the Netherlands has a product assortment of 2700 different products like artisans, food products, textiles, species, toys, wine, furniture and ornaments. The Dutch organization works with about 120 producer organizations in 30 different countries.

The products are distributed through the 400 Wereldwinkels (world shops) and 9 fair trade shops. An interview with a representative of the fair trade organization in the Netherlands revealed that natural chewing gum has been reviewed for acceptance as a fair trade product. The decision turned out to be negative because more and more the shops of fair trade shift towards gift shops instead of food stores. In their opinion the natural/organic food stores are a more appropriate distribution channel for natural chewing gum. 
There are many products that claim to be organically produced. Consumers often wonder how to verify whether the products is really organically produced. IFOAM (International Federation of Organic Agricultural Movement) operates an international accreditation program to provide the market guarantee of the organic certifications. Organic products certified by an IFOAM accredited certifying institution can be considered as organically produced according to IFOAM standards. Organic products are distributed through organic markets, organic food stores and more and more sold in regular supermarkets.

FSC certified products.

The Forest Stewardship Council manages an international labeling scheme for forest products, which provides a credible guarantee that the product comes from a wellmanaged forest. All forest products carrying the FSC-logo have been independently certified as coming from forests that meet the internationally recognized FSC Principles and Criteria of Forest Stewardship. In this way FSC provides an incentive in the market place for good forest stewardship. The forest inspections are carried out by a number of FSC accredited certification bodies which are evaluated and monitored to ensure their competence and credibility. Products with an FSC-logo are sold through the regular distribution channels for timber products. Products with FSC-logo can be find in retail stores such as Home Depot in the USA.

\section{Marketing approach of current products}

In this section, I will analyze the approach of each of the three natural chewing gums on the market in the US and how they use certification in production and marketing 
The three natural chewing gums on the market are: Speakeasy, (marketed in Mexico and the United States by Mexitrade), GleeGum, (marketed in the U.S. by of Verve Inc.) and JungleGum, (marketed by Wild Things Inc of Gainesville, FL.)

What packages and marketing strategies have in common is that the natural ingredients of the products are emphasized. Figure 16 compares the marketing message on the packages of each one of the gums, and what certification seals they have on their package.

16. Texts on Packaging of Natural Gums Marketed in the US

\begin{tabular}{|c|c|c|}
\hline $\begin{array}{l}\text { Brand } \\
\text { Names } \\
\end{array}$ & Text on Package & $\begin{array}{l}\text { Certification Noted on } \\
\text { Package }\end{array}$ \\
\hline Speakeasy & $\begin{array}{l}\text { 'Chewing gum, From the Rainforest, } 100 \% \\
\text { natural ingredients'. } \\
\text { Fairtrade message: } \\
6000 \text { Chiclero families farming } 80 \text { million } \\
\text { chicle trees in the rainforest. } \\
\text { Organic Messsage } \\
\text { Our chewing gum is made only from } \\
\text { natural chicle, and contains no plastic or } \\
\text { rubber, which is commonly used to make } \\
\text { GumBase in many chewing gums. } \\
\text { Ecological Sustainability message; } \\
\text { Tapping chicle from rainforest trees is non- } \\
\text { detrimental to the life of the tree or to the } \\
\text { environment. We practice proper rotational } \\
\text { harvesting and sustainable rainforest } \\
\text { management. }\end{array}$ & None \\
\hline GleeGum & $\begin{array}{l}\text { 'Finally all natural gum! Made with } \\
\text { rainforest chicle, the way gum used to be } \\
\text { made'. } \\
\text { Fairtrade message: } \\
\text { None } \\
\text { Organic message: } \\
\text { All natural gum. }\end{array}$ & None \\
\hline
\end{tabular}




\begin{tabular}{|l|l|l|}
\hline & $\begin{array}{l}\text { Ecological Sustainability message: } \\
\text { Made with rainforest chicle. }\end{array}$ & \\
\hline $\begin{array}{l}\text { Jungle } \\
\text { Gum }\end{array}$ & $\begin{array}{l}\text { 'Pure chicle; Jungle Gum, Triple Certified, } \\
\text { Organic Chewing Gum'. } \\
\text { Fairtrade message: } \\
\text { Wild Things is committed to respecting and } \\
\text { protecting the people and places that } \\
\text { enables us to bring you JungleGum. Risk } \\
\text { taking chicle collectors deserve to be paid } \\
\text { fairly for their hard work. }\end{array}$ & $\begin{array}{l}\text { Triple certified } \\
\text { 'Fair-Trade } \\
\text { 'FSC } \\
\text { 'Florida Organic } \\
\text { Grower' }\end{array}$ \\
$\begin{array}{l}\text { Organic message: } \\
\text { You care what you put in your mouth and } \\
\text { where it comes from. JungleGum is made } \\
\text { from chicle a natural sap from tropical } \\
\text { forest trees in Mexico, Guatemala and } \\
\text { Belize. Before introduction of petroleum- } \\
\text { based, plastic gums in the 1950s, chicle } \\
\text { was the source for all chewing gum. Our } \\
\text { chicle is collected and processed by hand in } \\
\text { specific communities throughout the Maya } \\
\text { forest region. }\end{array}$ & \\
\hline $\begin{array}{l}\text { Ecological Sustainability message: } \\
\text { You know that if we manage our natural } \\
\text { resources for sustainable production, they } \\
\text { will last forever. }\end{array}$ & \\
\hline
\end{tabular}

As can be seen from the table above, there are similarities in the claims made.

Only knowledgeable consumers might know what these messages on the packages mean. It is not common knowledge that chewing gum used to be made of natural chicle and nowadays is made of artificial ingredients.

The information on the package of GleeGum does not make any reference to the conservation of the rainforest. Simply referring to the ingredient of rainforest chicle does 
not imply any objectives in contributing to the conservation of the rainforest or to the sustainability of the production.

Speakeasy gives a little more information by referring to the fact that the chewing gum is coming from the rainforest and informs the consumer that tapping of chicle from the rainforest trees is non-detrimental to the life of the tree or to the environment. It is also stated that the company (Mexitrade) practices proper rotational harvesting and sustainable rainforest management. But these statements are not backed by an accredited certification institution.

The package of JungleGum also specifically refers to the conservation of the rainforest and to sustainable production. Specific reference is made to the certificate of the Forest Stewardship Council (FSC) obtained for the product. As described above in the beginning of this chapter FSC certification safeguards conservation of forest and sustainable exploitation of forests.

JungleGum also informs the consumer about the certification for organic production and the FairTrade certification they obtained for the product. Organic certification guarantees that the product is $100 \%$ natural and FairTrade certification guarantees that the producers are paid fairly.

Through certification and using the accredited labels of certification on the package the consumer is assured that reliable information is given about the product.

The two other brands, Speakeasy and GleeGum, lack such certification. This reveals that there has been no third part inspection of the claims made on the package and thus there is no way for the consumer to verify those claims. This leads these brands to 
be open to accusations of "greenwashing", that is, making unsubstantiated and unverifiable claims about the positive environmental qualities of the product.

The package of JungleGum and the package of Speakeasy both contain a picture of a chiclero climbing and tapping the tree. Through the presentation of this image they emphasize the traditional and exotic aspect of chicle and natural chewing gum. Also, GleeGum emphasizes the tradition in their slogan that natural chewing gum is made the way gum used to be made.

As was concluded in the section on the characteristics of organic food product consumers, there is a significant opportunity for marketing of natural chewing gum using its unique selling points of health and environmental protection. In that same section it was concluded that within the potential consumers of natural chewing gum there is only a relatively small percentage that make buying decisions based on effects on the environment. The majority of the potential consumers of natural chewing gum make buying decisions based on their health. None of the research on organic product and healthy lifestyle consumers mention tradition as a motivation for those consumers to buy a product.

The most important marketing problem is that the message that is communicated to the potential consumers does not completely synchronize with the buying motivations. As was described in the characteristics of the potential consumer groups of organic food products in Europe and in the US in the foregoing section, health is the main driver for consumers buying goods. In the marketing message of natural chewing gum, the health aspect should be emphasized. Although JungleGum and Speakeasy make reference to the contrast between natural chewing gum and petroleum based conventional chewing gums 
on their package, it is not known to the public that most chewing gum contains rubber and plastic. This specific health aspect of natural chewing gum should be emphasized more. The environmental aspect and, specifically, the contribution to the conservation of the rainforest should also be communicated to the consumer. Companies might want to reconsider their marketing message to bring it more in balance with the buying motivations of the potential consumer groups.

Certification can be considered as another marketing problem. It is not doubted that certification is contributing in informing the consumer about products in a reliable way, but it is questionable whether it contributes to the marketing and sales of the product. In the case of natural chewing gum, there were high expectations by the producers in Mexico that certification of the chicle production might boost their sales. There are certainly benefits e.g., a higher price than the market price is paid to the producers, but until now only by JungleGum, and the chicle production is part of the sustainable forest exploitation scheme under FSC management standards. However, sales were not increased significantly. It is not clear whether or how certification affects sales exactly, but it certainly did not deliver benefits consistent with the high expectations of the producers. 


\section{CONCLUSION}

There are many challenges to successful commercialization of NTFPs. The objectives of ecological sustainability and conservation of nature often seem to be opposed to the objectives of economic development and marketing. Analyzing aspects of the chicle activities resulted in interesting insights in the challenges this activity faces while developing commercialization. Main findings regarding the institutional structure, ecological and economical sustainability, marketing and markets are presented in this chapter.

The institutional structure strongly influences the success or failure of commercialization of NTFPs. An institutional system that maintains a continuous indebtedness of producers perpetuates poverty and limits economic progress. In the case of chicle the institutional structure has developed over time from a foreign controlled concession system to a government dominated export commodity, to a community level exploitation that characterizes the institutional structure today. The historically exploitative character of the chicle activity explains some of the problems in the current institutional structure. The fair amount of distrust of producers towards any intermediary organization is one of the most specific examples. But also the lack of transparency, lack of representation, low participation of producers in the decision making process, and the lack of direct market contacts at the producers' level may be explained by the exploitative historical institutional structure. The main challenge is to improve the institutional structure in a way that added value can be created locally and revenues are distributed more equally, eventually leading to an increase of revenues for producers. It is of the highest importance that the market dominance of Mexitrade is being challenged 
and that current strong international market contacts with the Union are maintained and extended. Market contacts between the buyers and the producers in the ejidos are also of importance, because this may stimulate innovative thinking about product development at the producers' level. The producers have to gain control over more parts of the commodity chain and added value has to be created locally. Fair-trade certification may help to obtain a higher price for the chicle product. Other certification schemes, as for organic production and sustainable forest management practices, may contribute to guaranteeing a $100 \%$ natural product and harvest practices that have the lowest possible impacts on the forests of Quintana Roo.

The market dominance of Mexitrade is a difficult barrier for the Union to face. This situation, combined with the lack of producers participation and lack of trust, are main elements in the institutional structure preventing a more equal distribution of income and the local generation of added value, currently severely limiting the economic development of chicle. Another important institutional finding is that the access and appropriation of chicle (individual) is different compared to the access and appropriation of timber (communal). It is important to acknowledge this difference and to take potential conflicts about the contribution to communal works into account. As far as producers' participation is concerned it is stressed that the entity of ejido has to be recognized as a political relevant actor. Ejidos and chicleros organizations and individuals have to be explicitly included into the further development of the chicle activity.

The ecological sustainability of chicle harvesting has been an issue during the times of overexploitation of the forests in the 1930s and 1940s. Nowadays, the harvesting 
of chicle forms part of the general forest activities. In Quintana Roo most of the community forests are managed under the Plan Piloto Forestal that has taken important steps toward the sustainable harvest of timber. In an effort to build on this successful model, chicle harvesting in many ejidos is now carried out under the umbrella of the Plan Piloto Chiclero. Since the end of the concession system and with current low market demand, it is not very likely that overexploitation will occur in the short term. It was shown earlier in chapter 4 that it has been estimated that current extraction is far below the productive potential of the forest. Ironically, it is the current underutilisation that mainly explains the current sustainable harvesting of chicle. Chicle contributes to the conservation of biodiversity in Quintana Roo because the activity implies leaving the chicozapote trees standing. The chicozapote tree is an important food source for wildlife in the forest. If the biodiversity of Quintana Roo's forest is to have a more certain future, then a diversified market for the forest's products and services is required. Such biodiversity markets may be based on diverse uses of all forest products and values: nature tourism, bird watchers, non profit conservation groups, the value of carbon sequestration by Quintana Roo's forests and so on. Chicle is an important part of this diversified use.

While all this might be environmentally positive, a continued underutilisation of the natural production capacity results in impoverishment and loss of income in some of the ejidos. Linkage to emerging markets for organic and fair-trade products may be a step forward in increasing production, sales and revenues for producers.

Because chicle is sold on developed markets, calculation of its extraction value is rather straightforward. Using Lampiettie's formula it was calculated that the extractive 
value of chicle in the ejido of Noh Bec is about US\$18.00 per hectare. Chicle also contributes to the non-extractive value of the forest because of the important role the activity plays in conservation strategies for the forests of Quintana Roo.

The seasonal income from chicle used to be a major source of income to the communities in Quintana Roo. Even though sales are now greatly reduced, it still provides for an attractive seasonal income for many that is complementary to income earned from working in timber during the other months of the year. As was concluded in Chapter 4 , compared to other types of forestry activities like logging, rail road tie production and honey, chicle provides the highest mean cash income for many chicleros. Thus, the income derived from chicle harvesting is attractive compared to other economic activities in the ejido. It provides for income in normally slow times for timber (the rainy season) and has the advantage of being an individual income not to be shared with other ejidatarios. The main threat to these positive elements for communities is the current low demand and prices in the chicle market.

Another problem is the unequal distribution of income along the commodity chain of chicle. As is the case with many NTFPs, most revenues are generated where value is added to the product. Over the years almost nothing has changed in the production of chicle. Locally, it never evolved from a low value added raw material to a more added value product (gum-base) or end product (chewing gum). Development plans regarding a gum-base factory in Quintana Roo, if they ever come to fruition, would be an important step in finally bringing more local added value to production.

Marketing networks of NTFPs determine whether harvest takes place in a monopolistic exploitative situation or in a situation beneficial for producers. As was 
referred to before, the lack of international marketing contacts on the producers' level makes the position of producers weak because they heavily depend upon the intermediary organization that represent them. This is certainly the case with chicle in Quintana Roo. Most of the chicleros have to rely upon information of the Union about prices and demand and are not in the position to get this information from other sources.

Another more severe problem is the low demand. Chicle is a typical example of a 'boom-and-bust' commodity. In the height of its boom it collapsed because it was replaced by a synthetic alternative that was cheaper. Now the main question is; do the emerging markets for organic and fair-trade products give chicle a second chance?

The consumer groups for organic and fair-trade products are constantly growing in the USA and in Europe. But organic and fair-trade chewing gum have some specific challenges of its own. Generally, the consumer of organic and fair-trade products is mainly driven by health reasons. Only a relatively small percentage considers environmental protection such as rainforest conservation as one of the main reasons to buy these types of products. Health might even prevent consumers buying chewing gum at all even though it would be natural chewing gum. On the other hand young organic product consumers might consider to restart or continue buying chewing gum when a natural alternative is on the market, provided that it is not much more expensive compared to conventional chewing gum.

Comparing the marketing message of the organic chewing gum to the characteristics of the potential consumers leads to the conclusion that the marketing messages place too much emphasis on the environmental aspect and the contribution of the product to the conservation of the rainforest. Health seems to be the main driver in 
the purchase decision of potential consumers in Europe and the USA. The organic and natural aspect of the natural chewing gum and the absence of artificial ingredients and additives should be emphasized more strongly.

It can be concluded that there is definitely a potential and growing market demand for organic products. For organic chewing gum, specifically, the challenge is to implement a strong marketing campaign that sends the right message in stressing the natural aspect of organic chewing gum. Other critical success factors are the quality of the natural chewing gum and the pricing of the natural gum product compared to conventional chewing gum. 


\section{LIST OF REFERENCES}

Aldrete2, Manuel. 2001. El Mercado Regional del Chicle Natural. Chetumal: Union de productores de chicle natural, presentation during 'Tercer Encuentro Chiclero Guatemala, Belice y Mexico', Chetumal, Mexico,August 2001.

Aldrete3, Manuel. 2001. Ficha Técnica. Analítico de Costos Directos (u.s.) / Kilogramo/Productor. Chetumal.

Barrera de Jorgenson, Amanda. 1993. Chicle extraction and Forest Conservation in Quintana Roo, Mexico., Latin American and Caribbean Studies, University of Florida, Gainsville.

Berkes, Fikret and Folke, Carl. 1998. Linking social and ecological systems for resilience and sustainability. Linking Social and Ecological Systems, The Press syndicate of the University of Cambridge.

Bray, David. 1995. Peasant Organizations and "The Permanent Reconstruction of Nature": Grassroots Sustainable Development in Rural Mexico. Journal of Environment and Development 4 (2):185-204.

Bray, David. 2001. Social dimensions of Organic Coffee Production in Mexico: Lessons for Eco-labeling Initiatives. Forthcoming in Society and Natural Resources.

Chicleros. 2001. Interviews. Chetumal.

Costanza, Robert, D'Arge, Ralph, de Groot, Rudolph. 1997. The Value of the World's Ecosystem Services and Natural Capital. Nature. 387.

Dugelby, Barbara, L. 1998. Governmental and Customary Arrangements Guiding Chicle Latex Extraction. In Timber, Tourists and Temples, edited by R. Primack, B, Bray, David. Washington D.C.: Island Press.

Ejido of Noh-Bec, 1999. Notificación para el aprovechamiento de latex de Chicozapote,. Noh Bec, Mexico.

Ejido.of Noh-Bec, 2001. Sueldos y Salarios Anualidad 2001. Noh Bec, Mexico.

Fox, Jonathan, Hernandez, Luis. 1992. Mexico's Difficult Democracy: Grassroots Movements, NGO's, and Local Government. Alternatives 17:165-208.

Fox, Jonathan. 1996. How Does Civil Society Thicken? The Political Construction of Social Capital in Rural Mexico. World Development 24 (6):1089-1103.

1997. The World Bank and Social Capital: Contesting the Concept in Practice. Journal of International Development 9 (7):963-971. 
Galetti, Hugo. 2001. Interview. Chetumal.

Galetti, Hugo, Flachsenberg, Henning. 1998. Forest Management in Quintana Roo. In Timber, Tourists and Temples, edited by D. Bray, R. Primack, I. Ponciano, Washington D.C.: Island Press.

Godoy, Ricardo, Lubowski, Ruben and Markandya, Anil. 1993. A method for the Economic Valuation of Non-Timber Tropical Forest Products. Economic Botany 47 (3):220-233 .

Hendrickson, R. 1976. The Great American Chewing Gum Book. Chilton Book Co, Radner, P.A.

Holling, C.S., Berkes, Fikret and Folke, Carl. 1998. Science, Sustainability and Resource Management. Linking Social and Ecological Systems, The Press syndicate of the University of Cambridge.

Kiernan, Michael and Freese, Curtis. Mexico's Plan Piloto Forestal. The Search for Balance between Socioeconomic and Ecological Sustainability. In Harvesting Wild Species. Implications for Biodiversity Conservation. Baltimore: John Hopkins University Press.

Konrad, H.W. 1986. Plantation labor systems in the tropical forests: the case of chewing gum tappers. In Plantations around the world. Baton Rouge: Louisiana State University, Agricultural Center.

Lampietti, Julian A., Dixon, John A. 1995. To See the Forest for the Trees: A Guide to Non-Timber Forest Benefits.: Worldbank.

Lemus, Juan Luis. 2001. Interview. Felipe Carillo Puerto: UNORCA.

Leyva Martinez, Marcario. 2001. Interview. Noh Bec.

Natural, Unión de Productores de Chicle. 2000. La producción de chicle en México. Chetumal.

Neumann, Roderick P, Eric Hirsch 2000. Commercialisation of Non-Timber Forest Products: Review and Analysis of Research, Center for International Forestry Research, Bogor, Indonesia.

O'Connor, M. 1994. Is Capitalism Sustainable? New York: The Guilford Press.

Ostrom, Elinor. Social Capital: a Fad or Fundamental Concept?: Center for the Study of Institutions, Population, and Environmental Change Workshop in Political Theory and Policy Analysis Indiana University. 
Ponce Jimenez, Martha Patricia 1990. La montana chiclera Campeche: vida cotidiana y trabajo (1900-1950), Centro de Investigaciones y Estudios Superiores en Antropologia Social, Mexico D.F.

Porter, Rober. 2000. Politico-Economic Restructuring and Mexico's Small Coffee Farmers. In Poverty or Development, edited by R. Tardanico, Rosenberg, Mark B. New York: Routeledge.

Ramírez Aguilar, Gerardo Alfonso. 1992. Aprovechamiento del látex de Chicozapote (Manilkara Zapota) y potencial productivo en Quintana Roo., Facultad de Agricultura y Zootecnia, Universidad Juárez del Estado de Durango., Chetumal.

Sarukhán, Larson. 2001. When the Commons Become less Tragic: Land Tenure, Social organization, and Fair Trade in Mexico. In Protecting the Commons: edited by Burger, Ostrom ed., Island Press, Washington D.C.

Sociedad de Productores Forestales Ejidales de Quintana Roo. 1993. Historia y Caracteristicas de la Organizacion Social de la Produccion Chiclera en Quintana Roo. Chetumal: Acuerdo Mexico Alemania.

Snook, L and Jorgenson, A. 1992. Madera, Chicle, Caza y Milpa, Contribuciones al Manejo Integral de las selvas de Quintana Roo, México., at Chetumal, Mexico.

Stiglitz, Joseph E. 2000. Formal and Informal Institutions. In Social Capital a Multifaceted Perspective: The International Bank for Reconstruction.

Taylor, Peter Leigh, Carol Zagin, 2000. Neoliberal reform and sustainable forest management in Quintana Roo, Mexico: Rethinking the institutional framework of the Forestry Pilot Plan. In Agricultur and Human Values 00: 1-16-2000.

Unión de Productores de Chicle Natural, Plan Piloto Chiclero, S.P.R. de R.I. Propuesta Integral para el Desarollo de un Plan Empresarial para la Reactivación de la Actividad Chiclera. Chetumal.

Union of chicle cooperatives,. 2000. La Produción de chicle en México. Chetumal, Mexico.

WCED, Our Common Future, Alternatives, Volume 17, no 2, 1990. 